REVIEW

\title{
Recent advances in understanding haemochromatosis: a transition state
}

\author{
K J H Robson, A T Merryweather-Clarke, E Cadet, V Viprakasit, M G Zaahl, J J Pointon, \\ D J Weatherall, J Rochette
}

J Med Genet 2004;41:721-730. doi: 10.1136/jmg.2004.020644

Mutations in the hepcidin gene HAMP and the hemojuvelin gene HJV have recently been shown to result in juvenile haemochromatosis $(\mathrm{JH})$. Hepcidin is an antimicrobial peptide that plays a key role in regulating intestinal iron absorption. Hepcidin levels are reduced in patients with haemochromatosis due to mutations in the HFE and HJV genes. Digenic inheritance of mutations in HFE and HAMP can result in either $\mathrm{JH}$ or hereditary haemochromatosis $(\mathrm{HH})$ depending upon the severity of the mutation in HAMP. Here we review these findings and discuss how understanding the different types of haemochromatosis and our increasing knowledge of iron metabolism may help to elucidate the host's response to infection.

See end of article for authors' affiliations

\section{Correspondence to:} Kathryn J H Robson, MRC Molecular Haematology Unit, Weatherall Institute of Molecular Medicine, Headley Way, Oxford, OX3 9DS, UK'

kathryn.robson@ imm.ox.ac.uk

Correspondence to: Alison T MerryweatherClarke, MRC Molecular Haematology Unit, Weatherall Institute of Molecular Medicine, Headley Way, Oxford, OX3 9DS, UK;

alison.hammer@ imm.ox.ac.uk

Revised version received 18 May 2004

Accepted for publication 20 May 2004
M utations in the hepcidin gene HAMP and the hemojuvelin gene $H J V$ have recently been shown to result in juvenile haemochromatosis $(\mathrm{JH})$, whereas digenic inheritance of mutations in HFE and HAMP can result in either $\mathrm{JH}$ or hereditary haemochromatosis $(\mathrm{HH})$. These findings are discussed below.

\section{HLA LINKED HAEMOCHROMATOSIS AND HFE}

In his monograph in 1935 Sheldon suggested that haemochromatosis might have a genetic basis. ${ }^{1}$ It was later found to be an autosomal recessive disease. ${ }^{2}$ After Marcel Simon demonstrated linkage of the haemochromatosis locus to the MHC class 1 molecule HLA-A3, ${ }^{3}$ it was presumed that hereditary haemochromatosis (HH) was a simple, autosomal recessive disorder restricted to people of north west European origin. In 1996, Feder and colleagues identified the HFE gene and showed that over $80 \%$ of patients were homozygous for the C282Y mutation in this gene. ${ }^{4}$ Other groups have subsequently confirmed that the majority of haemochromatosis patients are homozygous for the C282Y mutation in HFE..$^{5-7}$ Among the remainder, over $75 \%$ of those who carry a single copy of the C282Y mutation are also compound heterozygotes for the more prevalent but mild H63D mutation in HFE (reviewed by Merryweather-Clarke et $\left.a l^{8}\right)$. Population studies have demonstrated that the $\mathrm{C} 282 \mathrm{Y}$ mutation is restricted to people of north west European origin. ${ }^{89}$ Other, rarer HFE mutations and variants have been reported (fig l) (reviewed by Pointon $e t \mathrm{al}^{10}$ ), the majority of which have been found in conjunction with the C282Y mutation. However, a Vietnamese patient has been described who is homozygous for a novel splice site mutation. ${ }^{11}$ Another mutation appears to result in an autosomal dominant form of haemochromatosis (478delC) (Pointon et al, manuscript in preparation). It should be noted that $\mathrm{Hfe}^{-/-}$mice have a much more severe phenotype than $\mathrm{Hfe}^{\mathrm{Cys} / \mathrm{Cys}}$ mice $^{12}$ and this may help explain the severity of iron loading in these patients. Haemochromatosis due to mutations in $H F E$ is known as type 1 haemochromatosis (OMIM 235200). More males than females are affected. Onset is usually in the fourth decade for men and in the fifth for women.

The original paper describing the cloning of the HFE gene reported that the mRNA encoding HFE was most abundant in the liver, and that low levels of HFE mRNA were found in many other tissues. ${ }^{4}$ Subsequently, there has been a series of studies describing the use of antibodies raised against HFE peptides or bacterially expressed HFE for the localization of HFE in different tissues. Histochemical techniques have localized HFE to a number of different cell types, including Kupffer cells, ${ }^{13}$ the gastrointestinal tract, $^{14}$ placenta, ${ }^{15}$ epithelial cells and macrophages and monocytes, ${ }^{16}$ and crypt cells of the small intestine ${ }^{17}$ although some reports conflict. A variety of monoclonal and polyclonal antipeptide antibodies have been used in these studies. One problem with the work on human material has been the lack of quantitation of HFE in the tissues examined. This has been overcome in a very recent study that examined the expression of iron metabolism related mRNAs in the rat using quantitative PCR, in situ hybridization, and western blot analysis. ${ }^{18}$ The study showed that HFE is expressed primarily in hepatocytes, and at 10-fold lower levels in Kupffer cells. ${ }^{18}$

The cloning of the HFE gene paved the way for the identification of non-HFE related forms of

Abbreviations: $A C D$, anaemia of chronic disease; $A D$, Alzheimer's disease; $\beta_{2} M, \beta_{2}$-microglobulin; $\mathrm{Cp}^{-/-}$ mice, ceruloplasmin null mice; $\mathrm{JH}$, juvenile haemochromatosis; $\mathrm{HH}$, hereditary haemochromatosis; IEL, intra-epithelial lymphocytes; IL-6, interleukin 6; IRE, iron responsive element; $M H C$, major histocompatibility complex; NF- $\kappa B$, nuclear factor $\kappa B$; NRAMP1, natural resistance associated macrophage protein $1 ; \mathrm{Pcm}$, polycythaemic mice; PKAN, pantothenate kinase associated neurodegeneration; $\mathrm{SLC} 11 \mathrm{~A} 1$, solute carrier family 1 member $1 ; \operatorname{SLC} 11 \mathrm{~A} 2$, solute carrier family 1 member 2; TfR2, transferrin receptor 2; TFR2, transferrin receptor 2 gene 


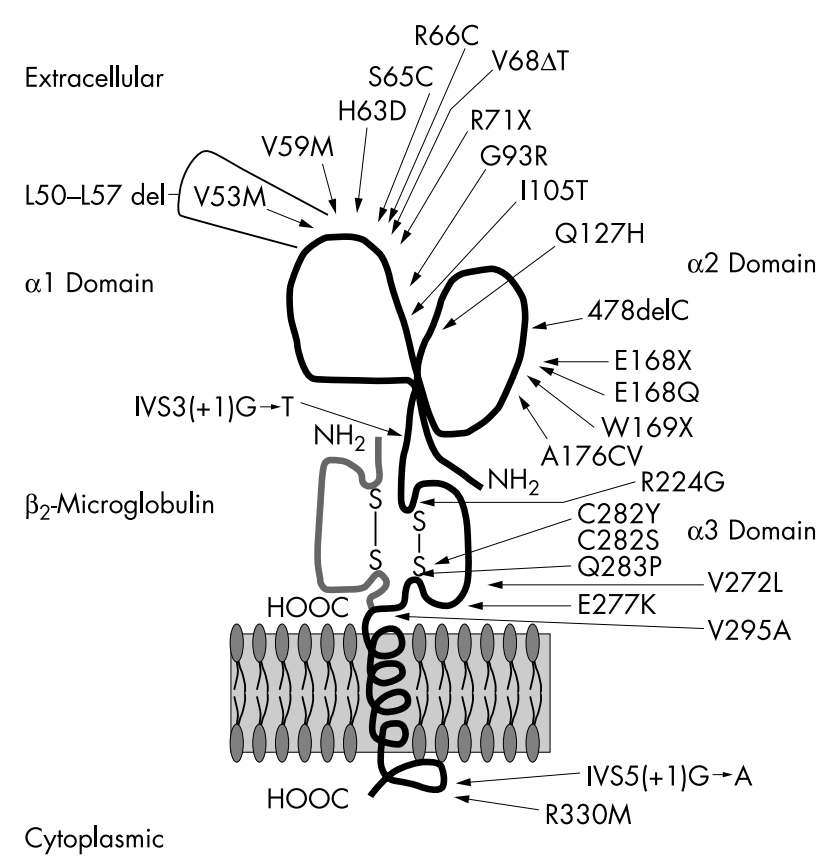

Figure 1 Representation of the $\mathrm{HFE} / \beta_{2}$-microglobulin complex adapted from Feder et $\mathrm{al}^{4}$ illustrating the relative positions of the different amino acid mutations and sequence variants in HFE.4 10 42 $156-170$ The approximate positions of the two splice site mutations relative to the appropriate exons have also been included. ${ }^{11}{ }^{171}$ The R6S mutation is in the signal sequence. ${ }^{172}$ The HFE protein is 343 amino acids long. The mature protein is 321 amino acids comprising three extracellular domains, $\alpha_{1}, \alpha_{2}$, and $\alpha_{3}$, with a single membrane spanning domain and a short cytoplasmic tail. It interacts with $\beta_{2}$-microglobulin $\left(\beta_{2} M\right)$ that is essential for the correct assembly of the HFE $/ \beta_{2} M$ complex. Unlike classical class I molecules there is no peptide binding groove between the $\alpha_{1}$ and $\alpha_{2}$ domains. The $\alpha_{3}$ domain is key to the interaction with $\beta_{2} M$. The four invariant cysteine residues form two disulphide bridges, one in the $\alpha_{2}$ domain and one in the $\alpha_{3}$. It is the C282Y mutation found in the majority of $\mathrm{HH}$ patients that disrupts this second disulphide bridge. The correct assembly of $\mathrm{HFE} / \beta_{2} \mathrm{M}$ results in cell surface presentation. The $\mathrm{C} 282 \mathrm{Y}$ form of HFE becomes stuck in the endoplasmic reticulum and middle Golgi. ${ }^{173} 174$

haemochromatosis, due to identification of mutations in a number of other genes. ${ }^{19-23}$ Analysis of these genes suggests that the pathway controlling the availability and uptake of iron is more complex that we had once thought. A list of genes with mutations leading to iron storage diseases together with their chromosomal locations, corresponding proteins, and previous names, is shown in table 1. Neonatal haemochromatosis may also have a hereditary component. ${ }^{24}$

\section{OTHER INHERITED FORMS OF \\ HAEMOCHROMATOSIS AND IRON OVERLOAD INCLUDING JUVENILE HAEMOCHROMATOSIS AND FERROPORTIN DISEASE}

Juvenile haemochromatosis $(\mathrm{JH})$, or type 2 haemochromatosis, is an autosomal recessive disease due to mutations in either the hepcidin $(H A M P)^{22}$ or hemojuvelin $(H J V)^{23}$ genes.

The clinical manifestations of $\mathrm{JH}$ and $\mathrm{HH}$ have been compared in detail. ${ }^{25}$ Equal numbers of males and females are affected by $\mathrm{JH}$, and cardiac involvement and hypogonadism are frequent in $\mathrm{JH}$.

$\mathrm{JH}$ is a more severe form of iron loading disorder than $\mathrm{HH}$, being characterised by an earlier age of onset, usually before the age of 30. A particularly severe form of $\mathrm{JH}$ is caused by autosomal inheritance of mutations in HAMP (OMIM 606464). ${ }^{22}$ The HAMP gene maps to $19 \mathrm{ql} 3$ and comprises three exons; the processed hepcidin peptide is coded entirely by exon $3 .{ }^{26}$ The first two $\mathrm{JH}$ mutations reported disrupt the reading frame for exon $3 .^{22}$ The first, $166 \mathrm{C} \rightarrow \mathrm{T}$, results in a premature termination codon $\mathrm{R} 56 \mathrm{X}$, and the second is a frameshift mutation (93delG) that alters the reading frame of exon $3 .^{22}$ The hepcidin peptide has four disulphide bonds, ${ }^{27}$ the third of which is disrupted by a missense HAMP mutation C70R resulting in $\mathrm{JH}^{28}{ }^{28}$ High levels of hepcidin result in anaemia ${ }^{29} 30$ and hyperferraemia. ${ }^{31-35}$

A second gene, HJV, has recently been identified that is involved in the same pathway as hepcidin. HJV mutations also result in $\mathrm{JH}$, with an autosomal recessive mode of inheritance. ${ }^{23} H J V$ maps to lq2 $1^{36}$ and encodes hemojuvelin (OMIM 608374). ${ }^{23} \mathrm{JH}$ due to mutations in $H J V$ appears to be less severe than that due to HAMP mutations. ${ }^{22}$ As is seen with mutations in the transferrin receptor 2 gene (TFR2), ${ }^{37-43}$ there is striking allele heterogeneity in $\mathrm{JH}$ due to mutations in $H J V$, with the majority of the mutations being private. ${ }^{23}{ }^{44-46}$ Most mutations generate premature termination codons or are missense substitutions affecting conserved amino acid residues. The 24 mutations described to date are summarized in table 2. The protein sequence of hemojuvelin has no hallmarks that explain its role in iron metabolism. Its expression is restricted to liver, heart, and skeletal muscle. Hemojuvelin is predicted to be a transmembrane protein, having both an Arg-Gly-Asp (RGD) motif and a partial von Willebrand factor type D domain. Many RGD motifs occur in cell surface proteins that interact with integrins in proteincell or cell-cell interactions. ${ }^{47}$ Hemojuvelin undergoes alternative splicing, ${ }^{23}$ the smallest of the spliced variants lacking the RGD motif. The longest isoform encodes a protein of 426 amino acids and shows sequence similarity with the repulsive guidance molecule. ${ }^{23}$ Urinary hepcidin levels are depressed in individuals with HJV linked JH, suggesting that hemojuvelin

Table 1 Examples of some of the genes in which mutations give rise to inherited forms of iron overload including haemochromatosis

\begin{tabular}{|c|c|c|c|c|c|c|}
\hline Gene & Previous names & Protein & $\begin{array}{l}\text { Chromosome } \\
\text { locus }\end{array}$ & Disease & Mode of inheritance & $\begin{array}{l}\text { Key } \\
\text { reference(s) }\end{array}$ \\
\hline HFE & $H L A-H$ & HFE & 6p21.3-6p22.1 & Haemochromatosis type 1 & Incomplete autosomal recessive & 4 \\
\hline HJV & HFE2 & Hemojuvelin & lq21 & Juvenile haemochromatosis & Autosomal recessive & 23 \\
\hline HAMP & HEPC & Hepcidin LEAP-1 & $19 q 13$ & Juvenile haemochromatosis & Autosomal recessive & 22 \\
\hline TFR2 & & Transferrin receptor 2 & $7 q 22$ & Haemochromatosis type 3 & Autosomal recessive & 19 \\
\hline SLC40A1 & $\begin{array}{l}\text { IREG1, MTP1, } \\
\text { SLC1 1A3, FPN1 }\end{array}$ & Ferroportin & $2 q 32$ & $\begin{array}{l}\text { Haemochromatosis type } 4 \\
\text { ferroportin disease }\end{array}$ & Autosomal dominant & 20,21 \\
\hline$H$-ferritin & & $\mathrm{H}$-ferritin & $11 q 13$ & $\begin{array}{l}\text { Autosomal dominant iron } \\
\text { overload }\end{array}$ & Autosomal dominant & 74 \\
\hline L-ferritin & & L-ferritin & $19 q 13.3-13.4$ & $\begin{array}{l}\text { Hyperferritinaemia/cataract } \\
\text { syndrome }\end{array}$ & Autosomal dominant & 75,76 \\
\hline & & Caeruloplasmin & $3 q 23-24$ & Acaeruloplasminaemia & Autosomal recessive & 80,81 \\
\hline PANK2 & & Pantothenate kinase 2 & 20p12.3-p13 & PKAN & Autosomal recessive & 109 \\
\hline
\end{tabular}


Table 2 HJV mutations that have been identified in patients with $\mathrm{JH}$

\begin{tabular}{|c|c|c|c|c|}
\hline $\begin{array}{l}\text { Nucleotide } \\
\text { change }\end{array}$ & Exon & Residue & Alleles & Reference(s) \\
\hline $18 G \rightarrow C$ & 2 & Q6H & 1 & 46 \\
\hline 220delG & 3 & V74fs X113 & 1 & 44 \\
\hline * & 3 & C80R & 1 & 45 \\
\hline $253 \mathrm{~T} \rightarrow \mathrm{C}$ & 3 & S85P & 2 & 44 \\
\hline $295 \mathrm{G} \rightarrow \mathrm{A}$ & 3 & G99R & 1 & 44 \\
\hline $296 G \rightarrow T$ & 3 & G99V & 1 & 23 \\
\hline $302 \mathrm{~T} \rightarrow \mathrm{C}$ & 3 & L101P & 2 & 44,46 \\
\hline $391-403 d d d e l$ & 3 & $\mathrm{R} 131 \mathrm{fs} \times 245$ & 2 & 44 \\
\hline $445 \mathrm{delG}$ & 3 & $\mathrm{R} 149 f_{\mathrm{s}} \times 245$ & 6 & 44 \\
\hline $503 C \rightarrow A$ & 3 & A168D & 2 & 44 \\
\hline $509 \mathrm{~T} \rightarrow \mathrm{C}$ & 3 & F170S & 4 & 44 \\
\hline $516 C \rightarrow G$ & 3 & D172E & 1 & 44 \\
\hline $573 G \rightarrow T$ & 3 & W191C & 2 & 44 \\
\hline $615 C \rightarrow G$ & 3 & S205R & 1 & 44 \\
\hline $665 \mathrm{~T} \rightarrow \mathrm{C}$ & $4 a$ & $1222 \mathrm{~N}$ & 2 & 23,45 \\
\hline $739 \mathrm{G} \rightarrow T$ & $4 a$ & G250V & 1 & 44 \\
\hline 806-807insA & $4 a$ & N269fsX311 & 1 & 44 \\
\hline $842 \mathrm{~T} \rightarrow \mathrm{C}$ & $4 a$ & $1281 \mathrm{~T}$ & 2 & 23,46 \\
\hline $863 C \rightarrow T$ & $4 a$ & R288W & 2 & 44 \\
\hline $954-955$ ins $G$ & $4 a$ & G319fsX341 & $\overline{1}$ & 44 \\
\hline $959 \mathrm{G} \rightarrow \mathrm{T}$ & $4 b$ & G320V & 46 & $23,44,45$ \\
\hline $962 \mathrm{G} \rightarrow \mathrm{A}$ & $4 b$ & C321X & 1 & 46 \\
\hline \multicolumn{5}{|l|}{$963 \mathrm{C} \rightarrow \mathrm{A}$} \\
\hline $976 C \rightarrow T$ & $4 b$ & R326X & 1 & 23 \\
\hline 1079delC & $4 b$ & C361fsX366 & 14 & 23 \\
\hline $1153 \mathrm{C} \rightarrow \mathrm{T}$ & $4 b$ & R385X & 4 & 44 \\
\hline
\end{tabular}

modulates hepcidin expression. ${ }^{23}$ Similar observations have been made for haemochromatosis expressing C282Y homozygotes. ${ }^{33}{ }^{35}$ HAMP mRNA levels in the liver of $\mathrm{HH}$ patients are inappropriately low for body iron stores and urinary levels are correspondingly low. ${ }^{33}$

In southern Italy, where a minority of haemochromatosis patients are $\mathrm{C} 282 \mathrm{Y}$ homozygotes, genome-wide screening of affected families led to the identification of another rare form of haemochromatosis caused by autosomal inheritance of mutations in the gene for TFR2. ${ }^{19}$ This is known as haemochromatosis type 3 (OMIM 604250) and is due to a number of private mutations. ${ }^{37-43}$ The first mutation, Y250X, was identified in two Sicilian families who were homozygous for a $C \rightarrow G$ transversion at nucleotide 750 in the coding sequence of the mRNA. ${ }^{19}$ A second nonsense mutation, missense and frameshift mutations have now been reported: $\mathrm{E} 60 \mathrm{X},{ }^{37} \mathrm{M} 172 \mathrm{~K},{ }^{37} \mathrm{R} 455 \mathrm{Q},{ }^{39} \mathrm{Q} 690 \mathrm{P},{ }^{38} \mathrm{~V} 221 \mathrm{I},{ }^{42}$ and the deletion of AVAQ (residues 594-597). ${ }^{39} 4043$ The clinical phenotype is similar to that of type 1 haemochromatosis, with iron deposition in the liver having a periportal distribution. However, the clinical features vary depending upon the reported mutation. ${ }^{37-43}$

Interestingly, transferrin receptor 2 (TfR2) is expressed in hepatocytes ${ }^{48}$ and in duodenal crypt cells ${ }^{17}$ as well as in platelets. ${ }^{49}$ Griffiths and Cox have demonstrated that HFE and TFR2 colocalise in duodenal crypt cells, and that within the crypt areas the distribution of TFR2 differed from that of transferrin receptor $1 .{ }^{17}$ Little or no HFE was present in the duodenal crypt cells of an $\mathrm{HH}$ patient and unlike the observed intracellular localisation of wildtype HFE, TFR2 localised to the basolateral surface of the duodenal crypt cell. These authors suggest that the interaction of HFE with TFR2 within this vesicular compartment was stimulated by the presence of holotransferrin (iron loaded transferrin). ${ }^{17}$ TFR2 plays a role in cellular iron transport although it has a 25 -fold lower affinity for transferrin relative to that of TFR1..$^{50}$

Type 4 haemochromatosis (OMIM 606069) is an autosomal dominant form of iron overload associated with mutations in the gene encoding ferroportin/IREGl/MTP1 (SLC40A1, previously SLC11A3). ${ }^{20}{ }^{21}$ The first description of this form of haemochromatosis was in a large kindred from the Solomon Islands..$^{52}$ Mutations in SLC4OAl have a wide geographical distribution..$^{53-58}$ One in particular, 162delVal, has been found in six unrelated families. ${ }^{59-62}$ Ferroportin is a membrane spanning transporter that exports iron from cells and is predicted to have nine or more transmembrane domains. Ferroportin is predominantly found in Kupffer cells and the basolateral membrane of the duodenal enterocyte. ${ }^{63-65} \mathrm{It}$ is also expressed in reticulo-endothelial macrophages, placental syncytiotrophoblasts, and hepatocytes.

The majority of ferroportin mutations localize to the external face of the protein in the model of Devalia et al, ${ }^{59}$ many of them mapping to the extracellular loop between transmembrane domains 3 and 4 (fig 2). It has been suggested that ferroportin expressed in the membrane of macrophages may interact with caeruloplasmin, a ferroxidase, to provide $\mathrm{Fe}^{3+}$ for transferrin. ${ }^{66}{ }^{67}$ The accumulation of iron by macrophages in patients with type 4 haemochromatosis suggests some loss of ferroportin function, possibly through a failure to interact with another protein such as caeruloplasmin. This is consistent with the phenotype of the ceruloplasmin null $\left(\mathrm{Cp}^{-/-}\right)$mouse in which iron accumulates in the Kupffer cells ${ }^{68}$ in a manner similar to that seen in patients with ferroportin mutations. Hephaestin plays an important role in intestinal iron absorption and is predicted to be a ferroxidase based on significant sequence identity to the serum multi-copper ferroxidase, ceruloplasmin. ${ }^{69}$ A recent report has shown that, in the rat, hephaestin is expressed both in the enterocyte and the macrophage, suggesting that caeruloplasmin may not be required as the ferroxidase in macrophages. ${ }^{18}$ Other mutations elsewhere in ferroportin may have the reverse effect, resulting in loss of regulation and enhanced export of iron from the macrophage (Viprakasit et al, unpublished observations). Disruption of ferroportin gene regulation causes dynamic alterations in iron homeostasis and erythropoiesis in polycythaemic mice. ${ }^{70}$ A $58 \mathrm{bp}$ microdeletion in the Slc40al promoter, identified in radiation induced polycythaemic mice $(P \mathrm{~cm})$, altered the transcription start sites and eliminated the iron responsive element (IRE) in the $5^{\prime}$ untranslated region. ${ }^{70}$ This resulted in increased duodenal and hepatic ferroportin protein levels during early postnatal development. Pcm mutant mice were iron deficient at birth and went on to develop reticuloendothelial iron overload as young adults. ${ }^{70}$ They also showed an erythropoietin dependent polycythaemia in heterozygotes and a hypochromic, microcytic anaemia in homozygotes. ${ }^{70}$ It was also observed that the defects in erythropoiesis were transient and that the delayed upregulation of hepcidin during postnatal development correlated with increased ferroportin levels and polycythaemia in Pcm heterozygotes. ${ }^{70}$

These findings will no doubt modify current models of how HFE mutations result in iron loading. ${ }^{67-73}$ In the model proposed by Townsend and Drakesmith HFE has two mutually exclusive activities in cells: inhibition of both uptake and release of iron from cells. ${ }^{71}$ The balance between transferrin saturation and transferrin receptor concentration would determine which of these two functions predominates. The inhibition of iron release may involve ferroportin. HFE present in the duodenal crypt cells and the reticuloendothelial system interprets the body's need for iron and thus controls iron absorption by the gut enterocyte and its subsequent distribution. Hence mutations in HFE would be predicted to result in over-absorption of dietary iron or its distribution.

Other rare forms of inherited disorders of iron metabolism have been reported. These include mutations in the IRE of $\mathrm{H}$ ferritin, ${ }^{74}$ and mutations in the IRE of L-ferritin which result 


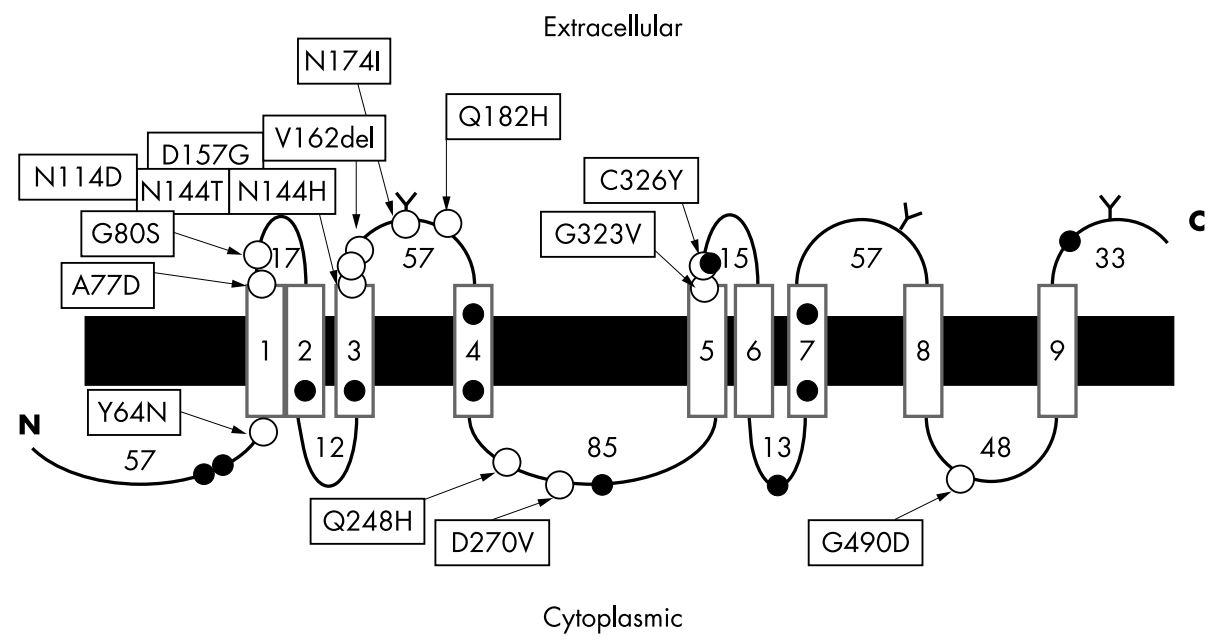

Figure 2 Schematic representation of the structure of ferroportin, based on the model proposed by Devalia et al. ${ }^{59}$ The filled circles correspond to the cysteine residues. The relative positions of the reported mutations are indicated by open circles. ${ }^{20}{ }_{21}^{53-62} 95 \mathrm{~A}$ third mutation at amino acid position 144 has just been reported associated with parenchymal loading and cirrhosis. ${ }^{175}$ We include two novel unpublished mutations, C326Y (Viprakasit et al, manuscript in preparation) and D270V (Zaahl et al, manuscript in preparation). The length in amino acids of the predicted loops and the position of three potential glycosylation sites $(Y)$ are indicated.

in the hyperferritinaemia-cataract syndrome. ${ }^{42}$ s4 $^{75-78}$ This syndrome has been reviewed recently. ${ }^{79}$ It is associated with low serum iron and elevated serum ferritin levels. Acaeruloplasminaemia results from mutations in caeruloplasmin. ${ }^{80}{ }^{81}$ This disease is characterised by iron accumulation in the brain and visceral organs; the involvement of the central nervous system distinguishes it from other inherited iron storage disorders. Acaeruloplasminaemia is associated with anaemia and low serum iron levels (for reviews see Gitlin $^{82}$ and Miyajima et $\left.a l^{83}\right)$. A total of 21 mutations in the caeruloplasmin gene have been identified in 24 families worldwide. ${ }^{82}$ Neurological problems such as ataxia and dementia are common, suggesting that iron efflux from storage sites within the CNS requires caeruloplasmin. The latter has a direct role in mobilising iron from parenchymal tissues by oxidising $\mathrm{Fe}^{2+}$ to $\mathrm{Fe}^{3+}$, enabling it to bind to circulating apo-transferrin..$^{83}$

\section{POPULATION GENETICS AND SCREENING}

The genetics of haemochromatosis is complicated by incomplete penetrance and digenic inheritance. Studies of various mouse models suggest that the inheritance of iron loading is more complex than was initially believed. A number of human population studies have demonstrated that there is a direct relationship between the HFE C282Y genotype and transferrin saturation. ${ }^{84-86}$ Transferrin saturation reflects the amount of transport iron that is available to cells via uptake through the transferrin receptor cycle. ${ }^{87}$ An unexplained raised transferrin saturation is usually an early biochemical indicator of haemochromatosis. The normal range has been the subject of debate. For men it is usually between 15-55\% and for women $15-50 \%$. The normal serum iron concentration is $10-30 \mu \mathrm{mol} / \mathrm{l}$. Patients who have haemochromatosis due to mutations in the HFE gene have transferrin saturations above $55 \%$ and also have a raised serum ferritin concentration (men $>300 \mu \mathrm{g} / \mathrm{l}$, women $>200 \mu \mathrm{g} / \mathrm{l}){ }^{88}$ However, not all C282Y homozygotes will show signs of iron loading. The age of onset is variable and is on average a decade later in women compared to men due to blood loss during menstruation and pregnancy. The presenting features are variable and lead to difficulties in diagnosis. Disease penetrance in haemochromatosis has been the subject of much recent discussion in the literature. ${ }^{89-93}$
It appears that disease is associated with a raised serum ferritin concentration, suggesting that there are genetic modifiers that contribute to increased serum ferritin concentrations in the presence of a raised transferrin saturation. This is supported by two observations. Firstly, mutations in ferroportin result in a phenotype that differs from that of HFE haemochromatosis. Patients with ferroportin mutations have a raised serum ferritin in the absence of a raised transferrin saturation. They rapidly become anaemic when treated by venesection unless they are also heterozygous for the H63D variant of HFE, and tend to have microcytic red cells. Iron loading in the liver is initially restricted to Kupffer cells, unlike that of HFE haemochromatosis in which iron is found predominantly in hepatocytes, with a periportal distribution; Kupffer cells are spared until the late phase of the disease progression. As a consequence, type 4 haemochromatosis has been referred to as "ferroportin disease" ${ }^{94}{ }^{95}$ Patients with HFE haemochromatosis tolerate venesection to mobilise their iron stores and their red cells tend to be macrocytic. ${ }^{96} 97$

The second observation suggesting that genetic modifiers influence serum ferritin concentration in the presence of increased transferrin saturation comes from work with mouse models of haemochromatosis. The degree of iron loading varies depending on the genetic background of the mouse. ${ }^{98}{ }^{99}$ Results presented at Bioiron 2003 suggested that there are at least four independent loci contributing to iron loading in the mouse model. ${ }^{100}$

Unfortunately, the phenotypic markers for haemochromatosis lack specificity and sensitivity. Transferrin saturation and serum ferritin levels are best evaluated together. A raised serum ferritin is not unique to a patient with haemochromatosis. Serum ferritin concentrations can be increased and transferrin saturation decreased in both acute and chronic disease. ${ }^{101}$ Due to variability in the age of onset of disease in HFE haemochromatosis, biochemical tests need to be repeated on a regular basis to identify those in the presymptomatic phase. Genetic screening for haemochromatosis is not currently deemed an acceptable alternative to phenotypic screening because of the incomplete penetrance of the C282Y homozygous state. The acceptability of screening must also be considered, although it may be more acceptable to screen for haemochromatosis than is currently thought (Cadet et al, submitted). Genetic screening for 
haemochromatosis may become more valuable when disease penetrance is better understood and it may be more appropriate in populations with a higher degree of penetrance. Reports from South Wales and California suggest low penetrance whereas much higher penetrance is seen in the Picardy region of northern France..$^{89} 93102103$ Environmental as well as genetic factors may help explain some of these differences.

In the future, screening for the $\mathrm{C} 282 \mathrm{Y}$ mutation may have other advantages. Although the $\mathrm{C} 282 \mathrm{Y}$ allele is not a high risk factor for diseases such as Alzheimer's or cardiovascular disease in isolation, in women who smoke or who have hypertension, it increases the risk of developing cardiovascular disease. ${ }^{104}$ The risk of myocardial infarction and atherosclerosis is related to iron stores. ${ }^{105}$ The HFE C282Y mutation is also a risk factor for Alzheimer's disease (AD) when present with the apolipoprotein E4 allele, a risk that is increased in the presence of the C2 allele of transferrin. ${ }^{106}$ Over 30 polymorphisms have been reported in the human transferrin gene. ${ }^{107}$ Of these, the $\mathrm{C} 2$ allele has a slightly reduced affinity for iron. If genetic screening for susceptibility to $\mathrm{AD}$ becomes a reality it may be worth including both HFE C282Y and TF C2 or routine monitoring of serum iron levels as part of a disease prevention programme. Increased circulating iron may induce the oxidative damage to lipids implicated in the genesis of common diseases such as cardiovascular disease and $\mathrm{AD}$, both of which involve plaque formation. Iron misregulation is known to play a role in pantothenate kinase associated neurodegeneration (PKAN; previously known as Hallervorden-Spatz disease), ${ }^{108}$ and has been implicated in other neurodegenerative disorders. ${ }^{109-112}$

\section{GENETIC MODIFIERS AND DIGENIC INHERITANCE}

Clues as to the complexity of factors resulting in iron loading disorders have come from recent work investigating haemochromatosis patients who carry only one copy of the HFE $\mathrm{C} 282 \mathrm{Y}$ mutation. We and others have found that some of them are heterozygous for mutations in HAMP. ${ }^{42} 113114$ This suggests that haemochromatosis can result from digenic inheritance of mutations in HFE and HAMP. The severity of disease correlates with the type of HAMP mutation. ${ }^{113}$ We identified two different mutations in $H A M P$, the more severe being a four nucleotide deletion, ATGG, at the $3^{\prime}$ end of exon 2 (Met50del IVS2+1 $(-G)$ ) which removes the splice site consensus GT but creates a second splice site consensus leading to a different open reading frame in exon $3 .{ }^{113}$ HAMP encodes hepcidin, which is synthesized in the liver as a prepropeptide and then processed to produce hepcidin. As the mature peptide is entirely encoded by exon $3,{ }^{32}$ no hepcidin is expressed by the Met50del IVS2+l $(-G)$ mutant allele, and heterozygosity for this and the C282Y mutation in HFE

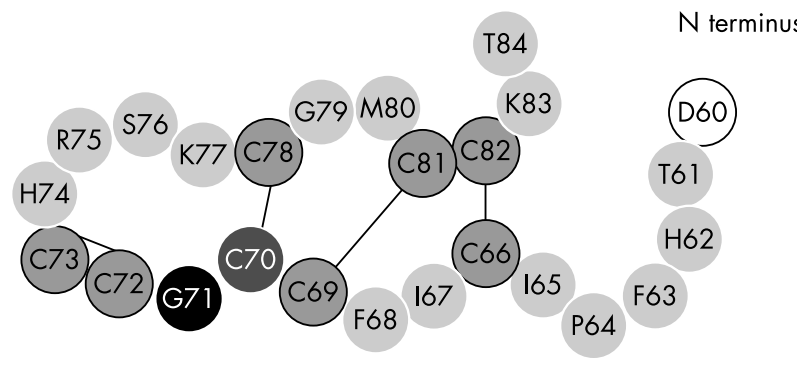

Figure 3 Schematic representation of the structure of hepcidin. ${ }^{27}$ The eight cysteine residues are indicated by black circles. The positions of the missense mutations G71D (black background) and C7OR (dark grey) are indicated. The only amino acid with an acidic side chain in the mature peptide, D60 (white background) is also indicated. The remaining amino acids are represented by light grey filled circles. results in $\mathrm{JH}^{113}$ Such patients presumably have half the functional levels of HFE and hepcidin, which act synergistically to produce disease. Double heterozygosity for the reported missense HAMP mutations (fig 3) and the HFE $\mathrm{C} 282 \mathrm{Y}$ mutation results in a milder disease that resembles the classic adult onset HFE haemochromatosis. ${ }^{42} 113114$ Consistent with these observations, hepcidin has been shown to act as a genetic modifier in the mouse model for haemochromatosis. ${ }^{115}$

Several groups have suggested that the ancestral haplotype carrying the $\mathrm{C} 282 \mathrm{Y}$ mutation is associated with more severe disease. ${ }^{116-118}$ Others have not been able to confirm this observation. ${ }^{119}$ The ancestral haplotype extends into the major histocompatibility complex (MHC) class I region. The extended MHC region includes genes involved in modulating the immune response, one of which is tumour necrosis factor $\alpha$. There are number of tumour necrosis factor $\alpha$ polymorphisms two which have been studied in relation to expression of $\mathrm{HH} .{ }^{120}$ These findings suggest that tumour necrosis factor $\alpha$ plays a role in $\mathrm{HH}$ by modulating the severity of the liver damage. ${ }^{120}$ One of the problems encountered in identifying the HFE gene was that it occurred on an extended haplotype. ${ }^{4}$ It is not clear whether other genes on this extended haplotype have provided a selective advantage. It has been proposed that the MHC class I genes may themselves be genetic modifiers and so explain the extended linkage disequilibrium. ${ }^{121}$

We have reported that the 16189 variant of mitochondrial DNA may also act as a modifier. ${ }^{122}$ Its frequency in the normal UK population is $8.8 \%$, increasing to $14.4 \%$ in disease expressing $\mathrm{C} 282 \mathrm{Y}$ homozygotes and decreasing to $3.2 \%$ in non-expressing homozygotes. ${ }^{122}$

Studies such as these need independent confirmation in a second population. Sampling error can sometimes lead to false disease associations.

\section{IRON, HOST DEFENCE, AND INFECTION}

The complex and controversial literature on the roles of iron deficiency or overload in susceptibility to infection is reviewed elsewhere. ${ }^{121} 123124$ It is not clear whether, in evolutionary terms, genetic diversity which favours increased iron absorption would have been advantageous. However, it is generally accepted that the hypoferraemia that occurs in acute infections, reflecting redistribution of iron rather than iron deficiency, may be an important mechanism for limiting iron availability for micro-organisms or parasites.

It is uncertain at present how mutations in some of the proteins described in this review result in iron overload. It is clear, however, that they are likely to be involved in a novel pathway of iron metabolism. That hepcidin is an acute phase protein $^{33}$ and HFE an MHC class I-like molecule ${ }^{4}$ suggests that other players in the pathway may well be involved in a host defence pathway that limits iron availability and restricts growth of invading pathogens.

Two groups identified hepcidin as an antimicrobial peptide. ${ }^{26}{ }^{125}$ Two separate approaches identified hepcidin as having a key role in iron homeostasis. ${ }^{31}{ }^{32}$ Loss of hepcidin expression in the mouse leads to severe iron overload ${ }^{31}$ and in humans a severe form $\mathrm{JH}$ is due to autosomal recessive inheritance of mutations in HAMP. ${ }^{22}$ The human gene encodes a pre-propeptide of 84 amino acids, ${ }^{26}$ which after cleavage of the signal sequence yields a propeptide of 60 amino acids that is cleaved further to give the 25 and 22 amino acid forms of hepcidin which is found in serum ${ }^{125}$ and urine. ${ }^{26}$ It is these 22 and 25 amino acid forms that have antibacterial $^{26}$ and antifungal activities. ${ }^{125}$ Hepcidin is a member of a family of proteins which includes the defensins, some of which have been shown to be involved in inflammation. Hepcidin is a cysteine-rich, cationic antimicrobial peptide and is a type II acute phase protein. ${ }^{33}$ 
Hepcidin regulates intestinal iron absorption. ${ }^{126}$ Elegant work by Nemeth and colleagues has shown that interleukin 6 (IL-6) mediates hypoferraemia of inflammation by inducing synthesis of hepcidin. ${ }^{127}$ This is a key finding as it helps explain the anaemia of chronic disease (ACD, also called the anaemia of inflammation). ACD is a hypoproliferative anaemia commonly found in patients with chronic infections, cancer, injury, and inflammatory disorders. ${ }^{128} 129$ Clinically, patients with ACD have a low serum iron (hyposideraemia) and reduced erythropoiesis due to low levels of erythropoietin. Inflammation increases retention of iron by the macrophage and restricts duodenal iron uptake. Hepcidin is key to this response. Mice lacking Hfe mount a general inflammatory response after injection of lipopolysaccharide but lack the appropriate hepcidin response and so do not develop hyposideraemia. ${ }^{130}$ Understanding the basis of ACD may help in developing new treatments.

HFE has a structure similar to MHC class I molecules. ${ }^{131}$ Importantly, these molecules form a heterodimer with $\beta_{2^{-}}$ microglobulin $\left(\beta_{2}-M\right)$. When mutations in HFE were first proposed to be responsible for $\mathrm{HH}$, supporting evidence came from the $\beta_{2}-\mathrm{M}$ null mouse. ${ }^{132}$ The iron loading observed in these mice recapitulated the iron loading observed in $\mathrm{HH}$. Mice lacking both $\mathrm{Hfe}$ and $\beta_{2}-\mathrm{M}$ have significantly greater iron overload that mice lacking either gene alone. ${ }^{133}$

Other proteins involved in iron metabolism include DMTl, the divalent metal ion transporter, ${ }^{134}$ which was originally identified as a gene with homology to natural resistance associated macrophage protein l (NRAMPl) and so given the name NRAMP2. ${ }^{135}$ NRAMPI is now classified as solute carrier family 1 member 1 (SLC1IAI) and NRAMP2 as solute carrier family 1 member 2 (SLC11A2). SLCllAl is expressed in spleen, liver, and lungs, but is most abundant in monocytes/ macrophages and polymorphonuclear leukocytes. ${ }^{136} 137$ The G169D mutation in the murine gene, Slcllal, is associated with susceptibility to infection with intracellular parasites such as Leishmania, Mycobacteria, and Salmonella. ${ }^{138}$ SLC1lAl has a role in the transport of divalent metals and so restricts the availability of divalent metal ions to phagocytosed pathogens in the phagosome. ${ }^{139}$ Within the phagolysosome SLCllAl is predicted to function in a pH dependent fashion, transporting divalent ions from the lumen of the phagolysosome thus restricting the growth of the pathogen. ${ }^{140}$

The iron transporter SLC11A2 has a major role in the transport of iron across the brush border into the enterocyte of the duodenum. It is also involved in transporting the iron released from transferrin in the lumen of recycling endosomes into the cytoplasm. ${ }^{141}$ Mutations in SLC11A2 result in anaemia. ${ }^{134}$

Further evidence suggesting that there is a pathway involving host defence and iron comes from the work of de Sousa and colleagues. ${ }^{142}$ They noted that the relative proportions of CD4+ and CD8+ T lymphocytes were abnormal in patients with $\mathrm{HH}$. Those with abnormally high iron stores have CD4:CD8 >3 (normal: 0.61-1.77). The abnormal ratio, due to abnormally low numbers of CD8 cells, remains unchanged after treatment by phlebotomy. ${ }^{143}$ In patients whose abnormal ratios persist after intensive treatment, the transferrin saturation starts to increase earlier than in those whose CD4:CD8 ratios are closer to the normal range. ${ }^{144}$ Anomalies of the $\mathrm{T}$ cell receptor repertoire have also been described in $\mathrm{C} 282 \mathrm{Y}$ carriers. ${ }^{145}$

Nuclear factor $\kappa \mathrm{B}(\mathrm{NF}-\kappa \mathrm{B})$ is a transcription factor that plays a pivotal role in transactivation of genes involved in the hepatic acute phase response and innate and adaptive immunity. ${ }^{146}$ One of the genes that it regulates, IL-6, is known to activate hepcidin. ${ }^{33}$ As discussed above, hepcidin plays a significant role in iron metabolism. ${ }^{30}{ }^{32}$ Endotoxin induced NF- $\kappa B$ activation in macrophages is inhibited by iron chelators, suggesting that intracellular iron plays a signalling role in NF- $\kappa \mathrm{B}$ activation. ${ }^{146}$ Tumour necrosis factor $\alpha$ expression is also induced by NF- $\kappa \mathrm{B}$. A model proposed by Chorney et $a l^{73}$ suggests that HFE may either signal directly to the intra-epithelial lymphocytes (IEL) or induce the expression of cell-surface or secreted molecules that carry out the signalling process. They suggest that iron loaded enterocytes would be viewed by a neighbouring $\gamma \delta$ IEL as being oxidatively stressed, in keeping with the role of $\gamma \delta \mathrm{T}$ cells in responding to tissue damage. ${ }^{147}$ The tumour necrosis factor $\alpha$ released could lead to an upregulation of ferritin expression and hence increased iron stores. ${ }^{148}$ This may provide yet another link between genes involved in iron metabolism and host immunity.

The haemoglobin scavenger receptor, CD163, is expressed on monocytes at low levels and at high levels on macrophages. ${ }^{149}$ IL-6, glucocorticoids, and IL-10 are acute phase mediators that strongly induce CDl63 mRNA and its expression at the cell surface. ${ }^{150}{ }^{151}$ LPS, IL-4, tumour necrosis factor $\alpha$, and interferon- $\gamma$ downregulate its expression. ${ }^{150}{ }^{151}$ It has been suggested that haptoglobin-haemoglobin complexes may crosslink CD163 on the macrophage surface and so trigger a cascade that increases the production and secretion of anti-inflammatory cytokines. ${ }^{152}$ This may provide further clues as to IL-6 production resulting in hepcidin expression and ACD. ${ }^{127} \mathrm{CD} 163$ may also play a role in atherosclerosis, ${ }^{153}$ again implicating iron in chronic disease.

HFE and hemojuvelin clearly operate upstream of hepcidin. Mice administered lipopolysaccharide have reduced levels of ferroportin mRNA and protein in the liver, spleen, and duodenum. ${ }^{154}$ Recent data suggest that hepcidin regulates ferroportin expression in the liver and intestine of the rat, suggesting that ferroportin is downstream of hepcidin in this pathway. ${ }^{155}$ Hepcidin could function by blocking the ferroportin linked iron export from enterocytes and macrophages. Some mutations in ferroportin would be predicted to alter this interaction, resulting in either enhanced or reduced export of iron from macrophages, as discussed above. The hepcidin receptor and the proteins involved in transcriptional control of ferroportin remain to be identified. From our experience there are still patients who have unexplained iron overload and may have mutations in other genes in the hepcidin pathway. Identification of these genes and their disease causing mutations will help fill the gaps in this pathway.

Clearly, the regulation of iron homeostasis and the inflammatory and immune responses are linked in a highly complex interactive system, many facets of which must have come under intense evolutionary pressure and which may show broad homology over many species. Hence they are likely to exhibit wide genetic heterogeneity, the further study of which may have important implications for a better understanding of both disorders of iron metabolism and their effects and the variability of response to infection among different ethnic groups.

\section{ACKNOWLEDGEMENTS}

The authors thank two reviewers for positive and constructive criticism.

\section{ELECTRONIC-DATABASE INFORMATION}

Accession numbers and URLs for data in this article are as follows: GenBank, http://www.ncbi.nlm.nih. gov/Genbank/ (for the haemochromatosis gene HFE); Online Mendelian Inheritance in Man (OMIM), http://www.ncbi.nlm.nih.gov/omim/ (for $\mathrm{HH}$ [OMIM 235200]; for juvenile haemochromatosis, HJV, HFE2A [OMIM 606374], HAMP, HFE2B [OMIM 606464]; for haemochromatosis due to mutations in TFR2, HFE3 [OMIM 604250]; for mutations in SLC4OA 1, HFE4 haemochromatosis [OMIM 606069]). 


\section{Authors' affiliations}

K J H Robson, A T Merryweather-Clarke, V Viprakasit, D J Weatherall, MRC Molecular Haematology Unit, Weatherall Institute of Molecular Medicine, Headley Way, Oxford, OX3 9DS, UK

E Cadet, J Rochette, Génétique Médicale-CHU, Faculté de Médecine, Université de Picardie Jules Verne, UMR-INERIS, Amiens, France V Viprakasit, Department of Paediatrics, Faculty of Medicine, Siriraj Hospital, Mahidol University, Bangkok, Thailand

M G Zaahl, Department of Genetics, University of Stellenbosch, Stellenbosch, South Africa

J J Pointon, Institute of Musculoskeletal Sciences, University of Oxford, The Botnar Research Centre, Nuffield Orthopaedic Centre, Windmill Road, Headington, Oxford, OX3 7LD, UK

Work in the laboratories of KJHR and JR has been supported by EC contract QLRT-1999-02237.

Conflict of interest: none declared.

\section{REFERENCES}

1 Sheldon JH. Haemochromatosis. Oxford: Oxford University Press, 1935

2 Saddi R, Feingold J. Idiopathic haemochromatosis: an autosomal recessive disease. Clin Genet 1974;5:234-41.

3 Simon M, Bourel M, Genetet B, Fauchet R. Idiopathic hemochromatosisdemonstration of recessive transmission and early detection by family HLA typing. N Engl J Med 1977;297:1017-21.

4 Feder JN, Gnirke A, Thomas W, Tsuchihashi Z, Ruddy DA, Basava A, Dormishian F, Domingo Jr R, Ellis MC, Fullan A, Hinton LM, Jones NL, Kimmel BE, Kronmal GS, Lauer P, Lee VK, Loeb DB, Mapa FA, McClelland E, Meyer NC, Mintier GA, Moeller N, Moore T, Morikang E, Prass CE, Quintana L, Starnes SM, Schatzman RC, Brunke KJ, Drayna DT, Risch NJ, Bacon BR, Wolff RK. A novel MHC class I-like gene is mutated in patients with hereditary haemochromatosis. Nat Genet 1996;13:399-408.

5 Jouanolle AM, Gandon G, Blayau M, Campion ML, Yaouanq J, Mosser J, Fergelot P, Chauvel B, Bouric P, Carn G, Andrieux N, Le Gall J-Y, David V. Haemochromatosis and HLA-H. Nat Genet 1996;14:251-2.

6 Jazwinska EC, Cullen LM, Busfield F, Pyper WR, Webb SI, Powell LP, Morris CP, Walsh TP. Haemochromatosis and HLA-H. Nat Genet 1996; 14:249-51.

7 Worwood M, Shearman JD, Wallace DF, Dooley JS, MerryweatherClarke AT, Pointon JJ, Rosenberg WMC, Bowen DJ, Burnett AK, Jackson HA, Lawless S, Raha-Chowdhury R, Partridge J, Williams R, Bomford A, Walker AP, Robson $\mathrm{KJH}$. A simple genetic test identifies $90 \%$ of UK patients with haemochromatosis. Gut 1997:41:841-4.

8 Merryweather-Clarke AT, Pointon JJ, Jouanolle AM, Rochette J, Robson KJH Geography of HFE C282Y and H63D mutations. Genet Test 2000;4:183-98.

9 Merryweather-Clarke AT, Pointon JJ, Shearman JD, Robson KJH. Global prevalence of putative haemochromatosis mutations. J Med Genet 1997;34:275-8

10 Pointon JJ, Wallace D, Merryweather-Clarke AT, Robson KJ. Uncommon mutations and polymorphisms in the hemochromatosis gene. Genet Test 2000;4:151-61

11 Steiner M, Ocran K, Genschel J, Meier P, Gerl H, Ventz M, Schneider M-L, Büttner C, Wadowska K, Kerner W, Schuff-Werner P, Lochs H, Schmidt H. A homozygous HFE gene splice mutation (IVS5+1G/A) in a hereditary hemochromatosis patient of Vietnamese origin. Gastroenterology 2002; 122:789-95

12 Levy JE, Montross LK, Cohen DE, Fleming MD, Andrews NC. The C282Y mutation causing hereditary hemochromatosis does not produce a null allele. Blood 1999:94:9-11.

13 Bastin JM, Jones M, O'Callaghan CA, Schimanski L, Mason DY, Townsend ARM. Kupffer cell staining by an HFE-specific monoclonal antibody: implications for hereditary haemochromatosis. $\mathrm{Br} J$ Haematol 1998;103:931-41.

14 Parkkila S, Waheed A, Britton RS, Feder JN, Tsuchihashi Z, Schatzman RC, Bacon BR, Sly WS. Immunohistochemistry of HLA-H, the protein defective in patients with hereditary hemochromatosis, reveals unique pattern of expression in gastrointestinal tract. Proc Natl Acad Sci U S A 1997;94:2534-9.

15 Parkkila S, Waheed A, Britton RS, Bacon BR, Zhou XY, Tomatsu S, Fleming RE, Sly WS. Association of the transferrin receptor in human placenta with HFE, the protein defective in hereditary hemochromatosis. Proc Natl Acad Sci U S A 1997;94:13198-202.

16 Parkkila S, Parkkila AK, Waheed A, Britton RS, Zhou XY, Fleming RE, Tomatsu S, Bacon BR, Sly WS. Cell surface expression of HFE protein in epithelial cells, macrophages, and monocytes. Haematologica 2000;85:340-5

17 Griffiths WJ, Cox TM. Co-localization of the mammalian hemochromatosis gene product (HFE) and a newly identified transferrin receptor (TFR2) in intestinal tissue and cells. J Histochem Cytochem 2003;51(5):613-24.

18 Zhang AS, Xiong S, Tsukamoto H, Enns CA. Localization of iron metabolismrelated $m R N A s$ in rat liver indicates that HFE is expressed predominantly in hepatocytes. Blood 2004; 103:1509-14.
19 Camaschella C, Roetto A, Cali A, De Gobbi M, Garozzo G, Carella M, Majorano N, Totaro A, Gasparini P. The gene TFR2 is mutated in a new type of haemochromatosis mapping to 7q22. Nat Genet 2000;25:14-5.

20 Montosi G, Donovan A, Totaro A, Garuti C, Pignatti E, Cassaneli S, Trenor CC, Gasparini P, Andrews NC, Pietrangelo A. Autosomal-dominant hemochromatosis is associated with a mutation in the ferroportin (SLC11A3) gene. J Clin Invest 2001;108:619-23.

21 Niajou OT, Vaessen N, Joosse $M$, Berghuis $B$, van Dongen JWF Breuning MH, Sniiders PJLM, Rutten WPF, Sandkuijl LA, Oostra BA, van Duijn CM, Heutink P. A mutation in SLC1 1A3 is associated with autosomal dominant hemochromatosis. Nat Genet 2001;28:213-4

22 Roetto A, Papanikoloau G, Politou M, Alberti F, Girelli D, Christakis J Loukopoulos D, Camaschella C. Mutant antimicrobial peptide hepcidin is associated with severe juvenile haemochromatosis. Nat Genet 2003;33:21-2.

23 Papanikolaou G, Samuels ME, Ludwig EH, MacDonald MLE, Franchini PL, Dubé M-P, Andres L, MacFarlane J, Sakellaropoulos N, Politou M, Nemeth E, Thompson KJ, Risler JK, Zaborowska C, Babakaiff R, Radomski CC, Pape TD, Davidas O, Christakis J, Brissot P, Lockitch G, Ganz T, Hayden MR, Goldberg YP. Mutations in HFE2 cause iron overload in chromosome 1qlinked juvenile hemochromatosis. Nat Genet 2004:36:77-82.

24 Kelly AL, Lunt PW, Rodrigues F, Berry PJ, Flynn DM, McKiernan PJ, Kelly DA, Mieli-Vergani G, Cox TM. Classification and genetic features of neonatal haemochromatosis: a study of 27 affected pedigrees and molecular analysis of genes implicated in iron metabolism. J Med Genet 2001;38:599-610.

25 Camaschella C. Juvenile hemochromatosis. In: Powell L, ed. Hereditary diseases of the liver, Vol 12. London: Baillière Tindall, 1998:227-35.

26 Park CH, Valore EV, Waring AJ, Ganz T. Hepcidin, a urinary antimicrobial peptide synthesized in the liver. J Biol Chem 2001;276:7896-910.

27 Hunter HN, Fulton DB, Ganz T, Vogel HJ. The solution structure of human hepcidin, a peptide hormone with antimicrobial activity that is involved in iron uptake and hereditary hemochromatosis. J Biol Chem 2002;277:37597-603

28 Roetto A, Daraio F, Porporato P, Caruso R, Cox TM, Cazzola M, Gasparini P, Piperno A, Camaschella C. Screening hepcidin for mutations in juvenile hemochromatosis: identification of a new mutation (C7OR). Blood 2004; 103:2407-9.

29 Weinstein DA, Roy CN, Fleming MD, Loda MF, Wolfsdorf JI, Andrews NC. Inappropriate expression of hepcidin is associated with iron refractory anemia: implications for the anemia of chronic disease. Blood 2002; 100:3776-81.

30 Nicolas G, Chauvet C, Viatte L, Dana JL, Bigard X, Devaux I, Beaumont C, Kahn $A$, Vaulont $S$. The gene encoding the iron regulatory peptide hepcidin is regulated by anemia. J Clin Invest 2002;1 10:1037-44.

31 Nicolas G, Bennoun M, Devaux I, Beaumont C, Grandchamp B, Kahn A, Vaulont S. Lack of hepcidin gene expression and severe tissue iron overload in upstream stimulatory factor 2 (USF2) knockout mice. Proc Natl Acad Sci U S A 2001;998:8780-5.

32 Pigeon $C$, Ilyin $G$, Courselaud $B$, Leroyer $P$, Turlin B, Brissot $P$, Loréal O. A new mouse liver-specific gene, encoding a protein homologous to human antimicrobial peptide hepcidin, is overexpressed during iron overload. J Biol Chem 2001;276:7811-9.

33 Nemeth E, Valore EV, Territo M, Schiller G, Lichtenstein A, Ganz T. Hepcidin, a putative mediator of anemia of inflammation, is a type II acutephase protein. Blood 2003;101:2461-3.

34 Bridle KR, Frazer DM, Wilkins SJ, Dixon JL, Purdie DM, Crawford DH, Subramanian VN, Powell LW, GJA, Ramm GA. Disrupted hepcidin regulation in HFE-associated haemochromatosis and the liver as a regulator of body iron homeostasis. Lancet 2003;361:669-73.

35 Kulaksiz H, Gehrke SG, Janetzko A, Rost D, Bruckner T, Kallinowski B, Stremmel W. Pro-hepcidin: expression and cell specific localization in the liver and its regulation in hereditary haemochromatosis, chronic renal insufficiency, and renal anaemia. Gut 2004;53:735-43.

36 Roetto A, Totaro A, Cazzola M, Ciciliano M, Bosia S, D'Ascola G, Carella M, Zelante L, Kelly AL, Cox TM, Gasparini P, Camaschella C. The juvenile hemochromatosis locus maps to chromosome lq. Am J Hum Genet 1999;64:1388-93

37 Roetto A, Totaro A, Piperno A, Piga A, Longo F, Garozzo G, Cali A, De Gobbi M, Gasparini P, Camaschella C. New mutations inactivating transferrin receptor 2 in hemochromatosis type 3. Blood 2001;97:2555-60.

38 Mattman A, Huntsman D, Lockitch G, Langlois S, Buskard N, Ralston D, Butterfield Y, Rodrigues P, Jones S, Porto G, Marra M, De Sousa M, Vatcher $G$. Transferrin receptor 2 (TfR2) and HFE mutational analysis in nonC282Y iron overload: identification of a novel TfR2 mutation. Blood 2002; 100:1075-7

39 Hofmann WK, Tong XJ, Ajioka RS, Kushner JP, Koeffler HP. Mutation analysis of transferrin-receptor 2 in patients with atypical hemochromatosis. Blood 2002;100:1099-100.

40 Girelli D, Bozzini C, Roetto A, Alberti F, Daraio F, Colombari R, Olivieri O, Corrocher R, Camaschella C. Clinical and pathologic findings in hemochromatosis type 3 due to a novel mutation in transferrin receptor 2 gene. Gastroenterology 2002;122:1295-302.

41 Roetto A, Daraio F, Alberti F, Porporato P, Cali A, De Gobbi M, Camaschella $C$. Hemochromatosis due to mutations in transferrin receptor 2. Blood Cell Mol Dis 2002;29:465-70.

42 Biasiotto G, Belloli S, Ruggeri G, Zanella I, Gerardi G, Corrado M, Gobbi E, Albertini A, Arosio P. Identification of new mutations of the HFE, hepcidin, and transferrin receptor 2 genes by denaturing HPLC analysis of individuals with biochemical indications of iron overload. Clin Chem 2003;49:1981-8. 
43 Hattori A, Wakusawa S, Hayashi H, Harashima A, Sanae F, Kawanaka M, Yamada G, Yano M, Yoshioka K. AVAQ 594-597 deletion of the TfR2 gene in a Japanese family with hemochromatosis. Hepatol Res 2003;26:154-6.

44 Lanzara C, Roetto A, Daraio F, Rivard SR, Ficarella R, Simard H, Cox TM Cazzola M, Piperno A, Gimenez-Roqueplo A-P, Grammatico P, Volinia S, Gasparini $P$, Camaschella $C$. The spectrum of hemojuvelin gene mutation in lq-linked juvenile hemochromatosis. Blood 2004; 103:4317-21.

45 Lee PL, Beutler E, Rao SV, Barton JC. Genetic abnormalities and juvenile hemochromatosis: mutations of the HJV gene encoding hemojuvelin. Blood 2004; 103:4669-71.

46 Huang FW, Rubio-Aliaga I, Kushner JP, Andrews NC, Fleming MD. Identification of a novel mutation (C321X) in HJV. Blood 2004 (May 11; epub ahead of print).

47 Giancotti FG, Ruoslahti E. Integrin signaling. Science 1999;285(5430): 1028-32.

48 Fleming RE, Migas MC, Holden CC, Waheed A, Britton RS, Tomatsu S, Bacon BR, Sly WS Transferrin receptor 2: continued expression in mouse liver in the face of iron overload and hereditary hemochromatosis. Proc Natl Acad Sci U S A 2000;97:2214-9.

49 Hannuksela J, Parkkila S, Waheed A, Britton RS, Fleming RE, Bacon BR, Sly WS. Human platelets express hemochromatosis protein (HFE) and transferrin receptor 2. Eur J Haematol 2003;70:201-6.

50 West AP Jr, Bennett MJ, Sellers VM, Andrews NC, Enns CA, Bjorkman PJ. Comparison of the interactions of transferrin receptor and transferrin receptor 2 with transferrin and the hereditary hemochromatosis protein HFE. J Biol Chem 2000;275(49):38135-8.

51 Pietrangelo A, Montosi G, Totaro A, Garuti C, Conte D, Cassanelli S, Fraquelli M, Sardini C, Vasta F, Gasparini P. Hereditary hemochromatosis in adults without pathogenic mutations in the hemochromatosis gene. N Engl J Med 1999;341:725-32.

52 Eason R, Adams P, Aston C, Searle J. Familial iron overload with possible autosomal dominant inheritance. Aust N Z J Med 1990;20:226-30.

53 Arden KE, Wallace DF, Dixon JL, Summerville L, Searle JW, Anderson GJ Ramm GA, Powell LW, Subramaniam VN. A novel mutation in ferroportin 1 is associated with haemochromatosis in a Solomon Islands patient. Gut 2003;52:1215-7.

54 Hetet G, Devaux I, Soufir N, Grandchamp B, Beaumont C. Molecular analyses of patients with hyperferritinemia and normal serum iron values reveal both $L$ ferritin IRE and 3 new ferroportin (SLC11A3) mutations. Blood 2003; 102:1904-10.

55 Jouanolle AM, Douabin-Gicquel V, Halimi C, Loreal $O$, Fergelot $P$, Delacour T, de Lajarte-Thirouard AS, Turlin B, Le Gall JY, Cadet E, Rochette J, David V, Brissot P. Novel mutation in ferroportin 1 gene is associated with autosomal dominant iron overload. J Hepatol 2003;39:286-9.

56 Rivard SR, Lanzara C, Grimard D, Carella M, Simard H, Ficarella R, Simard R, D'Adamo AP, De Braekeleer M, Gasparini P. Autosomal dominant reticuloendothelial iron overload (HFE type 4 ) due to a new missense mutation in the FERROPORTIN 1 gene (SLC11A3) in a large FrenchCanadian family. Haematologica 2003;88:824-6.

57 Gordeuk VR, Caleffi A, Corradini E, Ferrara F, Jones RA, Castro O, Onyekwere O, Kittles R, Pignatti E, Montosi G, Garuti C, Gangaidzo IT, Gomo ZA, Moyo VM, Rouault TA, MacPhail P, Pietrangelo A. Iron overload in Africans and African-Americans and a common mutation in the SLC40Al (ferroportin 1) gene. Blood Cell Mol Dis 2003;31:299-304.

58 Beutler E, Barton JC, Felitti VJ, Gelbart T, West C, Lee PL, Waalen J, Vulpe C. Ferroportin 1 (SLC40A1) variant associated with iron overload in AfricanAmericans. Blood Cell Mol Dis 2003:31:305-9.

59 Devalia V, Carter K, Walker AP, Perkins SJ, Worwood M, May A, Dooley JS Autosomal dominant reticulo-endothelial iron overload associated with a three base pair deletion in the ferroportin 1 gene (SLC11A3). Blood 2002; 100:695-7.

60 Roetto A, Merryweather-Clarke AT, Daraio R, Livesey K, Pointon JJ, Barbietola G, Piga A, Mackie PH, Robson KJH, Camaschella C. A valine deletion in ferroportin 1: a common mutation in hemochromatosis type 4 ? Blood 2002; 100:733-4.

61 Wallace DF, Pedersen P, Dixon JL, Stephenson P, Searle JW, Powell LW, Subramaniam VN. Novel mutation in ferroportin 1 is associated with autosomal dominant hemochromatosis. Blood 2002; 100:692-4.

62 Cazzola M, Cremonesi L, Papaioannou M, Soriani N, Kioumi A Charalambidou A, Paroni R, Romtsou K, Levi S, Ferrari M, Arosio P, Christakis J. Genetic hyperferritinaemia and reticuloendothelial iron overload associated with a three base pair deletion in the coding region of the ferroportin gene (SLC1 1A3). Br J Haematol 2002;1 19:539-46.

63 Donovan A, Brownlie A, Zhou Y, Shepard J, Pratt SJ, Moynihan J, Paw BH, Drejer A, Barut B, Zapata A, Law TC, Brugnara C, Lux SE, Pinkus GS, Pinkus JL, Kingsley PD, Palls J, Fleming MD, Andrews NC, Zon LI. Positional cloning of zebrafish ferroportin 1 identifies a conserved vertebrate iron exporter. Nature 2000;403:776-81.

64 McKie AT, Marciani P, Rolfs A, Brennan K, Wehr K, Barrow D, Miret S, Bomford A, Peters TJ, Farzeneh F, Hediger MA, Hentze MW, Simpson RJ. A novel duodenal iron-regulated transporter, IREGI, implicated in the basolateral transfer of iron to the circulation. Mol Cell 2000;5:299-309.

65 Abboud S, Haile DJ. A novel mammalian iron-regulated protein involved in intracellular iron metabolism. J Biol Chem 2000;275:19906-12.

66 Fleming RE, Sly WS. Ferroportin mutation in autosomal dominant hemochromatosis: loss of function, gain in understanding. J Clin Invest 2001; 108:521-2.

67 Frazer DM, Anderson GJ. The orchestration of body iron intake: how and where do enterocytes receive their cues? Blood Cell Mol Dis 2003;30:288-97.
68 Harris ZL, Durley AP, Man TK, Gitlin JD. Targeted gene disruption reveals an essential role for ceruloplasmin in cellular iron efflux. Proc Natl Acad Sci U S A 1999;96:10812-7

69 Vulpe CD, Kuo YM, Murphy TL, Cowley L, Askwith C, Libina N, Gitschier J, Anderson GJ. Hephaestin, a ceruloplasmin homologue implicated in intestinal iron transport, is defective in the sla mouse. Nat Genet 1999;21:195-9.

70 Mok H, Jelinek J, Pai S, Cattanach BM, Prchal JT, Youssoufian H, Schumacher A. Disruption of ferroportin 1 regulation causes dynamic alterations in iron homeostasis and erythropoiesis in polycythaemia mice. Development 2004;131(8):1859-68.

71 Townsend ARM, Drakesmith H. Role of HFE in iron metabolism, hereditary haemochromatosis, anaemia of chronic disease, and secondary iron overload. Lancet 2002;359:786-90.

72 Fleming RE, Sly WS. Mechanisms of iron accumulation in hereditary hemochromatosis. Annu Rev Physiol 2002;64:663-80.

73 Chorney MJ, Yoshida Y, Meyer PN, Yoshida M, Gerhard GS. The enigmatic role of the hemochromatosis protein (HFE) in iron absorption. Trend Mol Med 2003;9:118-25

74 Kato J, Fujikawa K, Kanda M, Fukuda N, Sasaki K, Takayama T, Kobune M, Takada K, Takimoto R, Hamada H, Ikeda T, Niitsu Y. A mutation, in the ironresponsive element of $\mathrm{H}$ ferritin mRNA, causing autosomal dominant iron overload. Am J Hum Genet 2001;69:191-7.

75 Beaumont C, Leneuve P, Devaux I, Scoazec JY, Berthier M, Loiseau MN, Grandchamp B, Bonneau D. Mutation in the iron responsive element of the $L$ ferritin mRNA in a family with dominant hyperferritinaemia and cataract. Nat Genet 1995;11:444-6.

76 Martin ME, Fargion S, Brissot P, Pellat B, Beaumont C. A point mutation in the bulge of the iron-responsive element of the $L$ ferritin gene in two families with the hereditary hyperferritinemia-cataract syndrome. Blood 1998;91:319-23.

77 Ciciliano M, Zecchina G, Roetto A, Bosio S, Infelise V, De Stefani S, Mazza U, Camaschella C. Hyperferritinemia-cataract syndrome: three recurrent mutations in the IRE of L-ferritin in Italian families. Haematologica 1999;84:489-92.

78 McLeod JL, Craig J, Gumley S, Roberts S, Kirkland MA. Mutation spectrum in Australian pedigrees with hereditary hyperferritinaemia-cataract syndrome reveals novel and de novo mutations. Br J Haematol 2002;118(4):1179-82.

79 Cazzola M. Hereditary hyperferritinaemia/cataract syndrome. Best Pract Res Clin Haematol 2002;15(2):385-98.

80 Harris ZL, Takahashi Y, Miyajima H, Serizawa M, MacGillivray RT, Gitlin JD. Aceruloplasminemia: molecular characterization of this disorder of iron metabolism. Proc Natl Acad Sci U S A 1995;92:2539-43.

81 Bosio S, De Gobbi M, Roetto A, Zecchina G, Leonardo E, Rizzetto M, Lucetti C, Petrozzi L, Bonuccelli U, Camaschella C. Anemia and iron overload due to compound heterozygosity for novel ceruloplasmin mutations. Blood 2002; 100:2246-8.

82 Gitlin JD. Aceruloplasminemia. Pediatr Res 1998;44:271-6.

83 Miyajima H, Takahashi Y, Kono S. Aceruloplasminemia, an inherited disorder of iron metabolism. Biometals 2003;16:205-13.

84 Merryweather-Clarke AT, Worwood M, Parkinson L, Mattock C, Pointon JJ, Shearman JD, Robson KJH. The effect of HFE mutations on serum ferritin and transferrin saturation in the Jersey population. $\mathrm{Br} J$ Haematol 1998:101:369-73.

85 Jackson HA, Carter K, Darke C, Guttridge MG, Ravine D, Hutton RD, Napier JA, Worwood M. HFE mutations, iron deficiency and overload in 10,500 blood donors. Br J Haematol 2001;114:474-84.

86 Deugnier $Y$, Jouanolle A-M, Chaperon J, Moirand R, Pithois C, Meyer J-F, Pouchard M, Lafraise B, Brigand A, Caserio-Schoenemann C, Adams P, LeGall J-Y, David V. Gender-specific phenotypic expression and screening strategies in $\mathrm{C} 282 \mathrm{Y}$-linked haemochromatosis. A study of 9396 French people. Br J Haematol 2002;118:1170-8.

87 Dautry-Varsat A, Ciechanover A, Lodish HF. pH and the recycling of transferrin during receptor-mediated endocytosis. Proc Natl Acad Sci U S A 1983;80:2258-62.

88 Robson KJH, Merryweather-Clarke AT, Pointon JJ, Shearman JD, Halsall DJ, Kelly A, Cox TM, Rosenberg WM, Howell M, Eccles D, Patch C, Fowler AV, Wallace DF, Camaschella C, Roetto A, Zecchina G, De Gobbi M, Gasparini P, Cadet E, Vandwalle JL, Capron D, Rochette J, Borot N, Demangel C, Dery R, Vinel JP, Pascal JP, Coppin H, Roth M-P. Diagnosis and management of haemochromatosis since the discovery of the HFE gene: a European experience. Br J Haematol 2000;108:31-9.

89 Beutler E, Felitti VJ, Koziol JA, Ho NJ, Gelbart T. Penetrance of 845G->A (C282Y) HFE hereditary haemochromatosis mutation in the USA. Lancet 2002;359:211-8

90 Beutler E, Felitti V, Koziol JA, Gelbart T. Clinical haemochromatosis in HFE mutation carriers. Lancet 2002;360:411-2.

91 Cox T, Rochette J, Camaschella C, Walker A, Robson K. Clinical haemochromatosis in HFE mutation carriers. Lancet 2002:360:412.

92 Allen KJ, Warner B, Delatycki MB. Clinical haemochromatosis in HFE mutation carriers. Lancet 2002;360:412-3.

93 McCune A, Worwood M. Penetrance in hereditary hemochromatosis. Blood 2003;102:2696; author reply 2696-7.

94 Cazzola M. Genetic disorders of iron overload and the novel "ferroportin disease". Haematologica 2003;88:721-4.

95 Pietrangelo A. The ferroportin disease. Blood Cell Mol Dis 2004;32:21-9.

96 Barton JC, Bertoli LF, Rothenberg BE. Peripheral blood erythrocyte parameters in hemochromatosis: evidence for increased erythrocyte hemoglobin content. J Lab Clin Med 2000;135:96-104. 
97 Bolan CD, Conry-Cantilena C, Mason G, Rouault TA, Leitman SF. MCV as a guide to phlebotomy therapy for hemochromatosis. Transfusion $2001 ; 41: 819-27$.

98 Fleming RE, Holden CC, Tomatsu S, Waheed A, Brunt EM, Britton RS Bacon BR, Roopenian DC, Sly WS. Mouse strain differences determine severity of iron accumulation in Hfe knockout model of hereditary hemochromatosis. Proc Natl Acad Sci U S A 2001;98:2707-11.

99 Dupic F, Fruchon S, Bensaid M, Borot N, Radosaljevic M, Loreal O, Brissot P, Gilfillan S, Bahram S, Coppin H, Roth M-P. Inactivation of the hemochromatosis gene differentially regulates duodenal expression of ironrelated mRNAs between mouse strains. Gastroenterology 2002; 122:745-51

100 Bensaid M, Frucon S, Mazares C, Bahram S, Borot N, Coppin H, Roth M-P. A genome screen for modifier genes influencing iron accumulation in a murine model for hereditary hemochromatosis. Presented at Bioiron 2003, Bethesda, MD, USA, 2003 (poster).

101 Distante S, Berg JP, Lande K, Haug E, Bell H. HFE gene mutation (C282Y) and phenotypic expression among a hospitalised population in a high prevalence area of haemochromatosis. Gut 2000:47:575-9.

102 McCune CA, Al-Jader LN, May A, Hayes SL, Jackson HA, Worwood M. Hereditary haemochromatosis: only 1\% of adult HFE C282Y homozygotes in South Wales have a clinical diagnosis of iron overload. Hum Genet 2002;111:538-43.

103 Cadet E, Capron D, Perez AS, Crépin SN, Arlot S, Ducroix J-P, Dautréaux M, Fardellone P, Leflon P, Merryweather-Clarke AT, Livesey KJ, Pointon JJ, Rose P, Harcourt J, Emery J, Sueur JM, Feyt R, Robson KJH, Rochette J. A targetted approach significantly increases the identification rate of patients with undiagnosed haemochromatosis. J Intern Med 2003;253:217-24.

104 Roest M, van der Schouw YT, de Valk B, Marx JJM, Tempelman MJ, de Groot PG, Sixma JJ, Banga JD. Heterozygosity for a hereditary hemochromatosis gene is associated with cardiovascular death in women. Circulation 1999; 100:1268-73.

105 Fuchs J, Podda M, Packer L, Kaufmann R. Morbidity risk in HFE associated hereditary hemochromatosis C282Y heterozygotes. Toxicology 2002;180(2): 169-81

106 Robson KJH, Lehmann DJ, Wimhurst VLC, Livesey KJ, Combrinck M, Merryweather-Clarke AT, Warden DR, Smith AD. Synergy between the C2 allele of transferrin and the C282Y allele of the haemochromatosis gene (HFE) as risk factors for developing Alzheimer's disease. J Med Genet 2004;41:261-5.

107 Welch S, Langmead L. A comparison of the structure and properties of normal human transferrin and a genetic variant of human transferrin. Int J Biochem 1990;22:275-82.

108 Zhou B, Westaway SK, Levinson B, Johnson MA, Gitschier J, Hayflick SJ. A novel pantothenate kinase gene (PANK2) is defective in Hallervorden-Spatz syndrome. Nat Genet 2001;28:345-9.

109 Dexter DT, Carayon A, Javoy-Agid F, Agid Y, Wells FR, Daniel SE, Lees AJ, Jenner $P$, Marsden CD. Alterations in the levels of iron, ferritin and other trace metals in Parkinson's disease and other neurodegenerative diseases affecting the basal ganglia. Brain 1991;114:1953-75.

110 Gorell JM, Ordidge RJ, Brown GG, Deniau JC, Buderer NM, Helpern JA. Increased iron-related MRI contrast in the substantia nigra in Parkinson's disease. Neurology 1995;45:1138-43.

111 Curtis AR, Fey C, Morris CM, Bindoff LA, Ince PG, Chinnery PF, Coulthard A, Jackson MJ, Jackson AP, McHale DP, Hay D, Barker WA, Markham AF, Bates D, Curtis A, Burn J. Mutation in the gene encoding ferritin light polypeptide causes dominant adult-onset basal ganglia disease. Nat Genet $2001 ; 28: 350-4$

$112 \mathrm{Ke} \mathrm{Y,} \mathrm{Qian} \mathrm{ZM.} \mathrm{Iron} \mathrm{misregulation} \mathrm{in} \mathrm{the} \mathrm{brain:} \mathrm{a} \mathrm{primary} \mathrm{cause} \mathrm{of}$ neurodegenerative disorders. Lancet Neurol 2003;2:246-53.

113 Merryweather-Clarke AT, Cadet E, Bomford A, Capron D, Viprakasit V, Miller A, McHugh PJ, Chapman RW, Pointon JJ', Wimhurst VLC, Livesey KJ, Tanphaichitr V, Rochette J, Robson KJ. Digenic inheritance of mutations in HAMP and HFE results in different types of haemochromatosis. Hum Mol Genet 2003:12:2241-7.

114 Jacolot S, Le Gac G, Scotet V, Quere I, Mura C, Ferec C. HAMP as a modifier gene that increase the phenotypic expression of the HFE p.C282Y homozygous genotype. Blood 2004;103:2835-40.

115 Nicolas G, Andrews NC, Kahn A, Vaulont S. Hepcidin, a candidate modifier of the hemochromatosis phenotype in mice. Blood 2003;103:2841-3.

116 Crawford DH, Powell LW, Leggett BA, Francis JS, Fletcher LM, Webb SI, Halliday JW, Jazwinska EC. Evidence that the ancestral haplotype in Australian hemochromatosis patients may be associated with a common mutation in the gene. Am J Hum Genet 1995:57:362-7.

117 Piperno A, Arosio C, Fargion S, Roetto A, Nicoli C, Girelli D, Sbaiz L, Gasparini P, Boari G, Sampietro M, Camaschella C. The ancestral hemochromatosis haplotype is associated with a severe phenotype expression in Italian patients. Hepatology 1996;24:43-6.

118 Piperno A, Sampietro M, Pietrangelo A, Arosio A, Lupica L, Montosi G, Vergani A, Fraquelli M, Girelli D, Pasquero P, Roetto A, Gasparini P, Fargion S, Conte D, Camaschella C. Heterogeneity of hemochromatosis in Italy. Gastroenterology 1998;114:996-1002.

119 Distante S, Robson KJ, Graham-Campbell J, Arnaiz-Villena A, Brissot P, Worwood M. The origin and spread of the HFE-C282Y haemochromatosis mutation. Hum Genet 2004, in press.

120 Fargion S, Valenti L, Dongiovanni P, Scaccabarozzi A, Fracanzani AL, Taioli E, Mattioli M, Sampietro M, Fiorelli G. Tumor necrosis factor alpha promoter polymorphisms influence the phenotypic expression of hereditary hemochromatosis. Blood 2001;97:3707-12.

121 Cardoso CS, de Sousa M. HFE, the MHC and hemochromatosis: paradigm for an extended function for MHC class I. Tissue Antigens 2003;61:263-75.
122 Livesey KJ, Wimhurst VL, Carter K, Worwood M, Cadet E, Rochette J, Roberts AG, Pointon JJ, Merryweather-Clarke AT, Bassett ML, Jouanolle AM, Mosser A, David V, Poulton J, Robson KJ. The 16189 variant of mitochondrial DNA occurs more frequently in C282Y homozygotes with haemochromatosis than those without iron loading. J Med Genet 2004;41:6-10.

123 Hershko C, Peto TE, Weatherall DJ. Iron and infection. Br Med J (Clin Res Ed) 1988;296:660-4.

124 Marx JJ. Iron and infection: competition between host and microbes for a precious element. Best Pract Res Clin Haematol 2002;15:411-26.

125 Krause A, Neitz S, Magert HJ, Schulz A, Forssmann WG, Schulz-Knappe P, Adermann K. LEAP-1, a novel highly disulfide-bonded human peptide, exhibits antimicrobial activity. FEBS Lett 2000;480:147-50.

126 Laftah AH, Ramesh B, Simpson RJ, Solanky N, Bahram S, Schumann K, Debnam ES, Srai SK. Effect of hepcidin on intestinal iron absorption in mice. Blood 2004; 103:3940-4

127 Nemeth E, Rivera S, Gabayan V, Keller C, Taudorf S, Pedersen BK, Ganz T. IL-6 mediates hypoferremia of inflammation by inducing the synthesis of the iron regulatory hormone hepcidin. J Clin Invest 2004;113:1271-6.

128 Lee G. The anemia of chronic disease. Semin Haematol 1983;20:61-80.

129 Means RT Jr. The anaemia of infection. Bailliere's Best Pract Res Clin Haematol 2000;13:151-62.

130 Roy CN, Custodio AO, de Graaf J, Schneider S, Akpan I, Montross LK, Sanchez M, Gaudino A, Hentze MW, Andrews NC, Muckenthaler MU. An Hfe-dependent pathway mediates hyposideremia in response to lipopolysaccharide-induced inflammation in mice. Nat Genet 2004;36:481-5.

131 Lebrón JA, Bennett MJ, Vaughn DE, Chirino JA, Snow PM, Mintier GA, Feder JN, Bjorkman PJ. Crystal structure of the hemochromatosis protein HFE and characterization of its interaction with the transferrin receptor. Cell 1998:93:111-23.

132 de Sousa M, Reimão R, Lacerda R, Hugo P, Kaufmann SHE, Porto G. Iron overload in $\beta_{2}$-microglobulin-deficient mice. Immunol Lett 1994;39:105-11.

133 Levy JE, Montross LK, Andrewes NC. Genes that modify the hemochromatosis phenotype in mice. J Clin Invest 2000;105:1209-16.

134 Fleming MD, Romano MA, Su MA, Garrick LM, Garrick MD, Andrews NC. Nramp2 is mutated in the anemic Belgrade (b) rat: evidence of a role for Nramp2 in endosomal iron transport. Proc Natl Acad Sci U S A 1998:95:1148-53.

135 Gruenheid S, Cellier M, Vidal S, Gros P. Identification and characterization of a second mouse Nramp gene. Genomics 1995;25:514-25.

136 Cellier M, Govoni G, Vidal S, Kwan T, Groulx N, Liu J, Sanchez F, Skamene E, Schurr E, Gros P. Human natural resistance-associated macrophage protein: cDNA cloning, chromosomal mapping, genomic organization, and tissue-specific expression. J Exp Med 1994; 180:1741-52.

137 Cellier M, Shustik C, Dalton W, Rich E, Hu J, Malo D, Schurr E, Gros P Expression of the human NRAMP1 gene in professional primary phagocytes: studies in blood cells and in $\mathrm{HL}-60$ promyelocytic leukemia. J Leuk Biol 1997;61:96-105.

138 Skamene E, Forget A. Genetic basis of host resistance and susceptibility to intracellular pathogens. Adv Exp Med Biol 1988;239:23-37.

139 Jabado N, Jankowski A, Dougaparsad S, Picard V, Grinstein S, Gros P. Natural resistance to intracellular infections: natural resistance-associated macrophage protein 1 (Nrampl) functions as a pH-dependent manganese transporter at the phagosomal membrane. J Exp Med 2000;192:1237-48.

140 Hackam DJ, Rotstein OD, Zhang W, Gruenheid S, Gros P, Grinstein S. Host resistance to intracellular infection: mutation of natural resistance-associated macrophage protein 1 (Nrampl) impairs phagosomal acidification. J Exp Med 1998; 188:351-64.

141 Gruenheid S, Cannone-Hergaux F, Gauthier S, Hackam DJ, Grinstein S, Gros $P$. The iron transport protein NRAMP2 is an integral membrane glycoprotein that colocalizes with transferrin in recycling endosomes. J Exp Med 1999; 189:831-41.

142 de Sousa M, Porto $G$. The immunological system in hemochromatosis. J Hepatol 1998;28:1-7.

143 Porto G, Vicente C, Teixeira MA, Martins O, Cabeda JM, Lacerda R, Goncalves C, Fraga J, Macedo G, Silva BM, Alves H, Justica B, de Sousa M. Relative impact of HLA phenotype and CD4-CD8 ratios on the clinical expression of hemochromatosis. Hepatology 1997;25:397-402.

144 Reimão R, Porto G, de Sousa M. Stability of CD4/CD8 ratios in man: new correlation between CD4/CD8 profiles and iron overload in idiopathic haemochromatosis patients. C R Acad Sci III 1991;313:481-7.

145 Cardoso C, Porto G, Lacerda R, Resende D, Rodrigues P, Bravo F, Oliveira JC, Justica B, de Sousa M. T-cell receptor repertoire in hereditary hemochromatosis: a study of 32 hemochromatosis patients and 274 healthy subjects. Hum Immunol 2001;62:488-99.

146 Xiong S, She $\mathrm{H}$, Takeuchi $\mathrm{H}$, Han B, Engelhardt JF, Barton $\mathrm{CH}$, Zandi E, Giulivi C, Tsukamoto H. Signaling role of intracellular iron in NF-kappaB activation. J Biol Chem 2003;278:17646-54.

147 Boismenu R, Havran WL. Modulation of epithelial cell growth by intraepithelial gamma delta T cells. Science 1994;266:1253-5.

148 Kwak EL, Larochelle DA, Beaumont C, Torti SV, Torti FM. Role for NF-kappa $\mathrm{B}$ in the regulation of ferritin $\mathrm{H}$ by tumor necrosis factor-alpha. J Biol Chem 1995;270:15285-93.

149 Sanchez C, Domenech N, Vazquez J, Alonso F, Ezquerra A, Dominguez J. The porcine $2 \mathrm{~A} 10$ antigen is homologous to human $\mathrm{CD} 163$ and related to macrophage differentiation. J Immunol 1999;162:5230-7.

150 Sulahian TH, Hogger P, Wahner AE, Wardwell K, Goulding NJ, Sorg C, Droste A, Stehling M, Wallace PK, Morganelli PM, Guyre PM. Human 
monocytes express CD163, which is upregulated by IL-10 and identical to p155. Cytokine 2000;12:1312-21.

151 Schaer DJ, Boretti FS, Schoedon G, Schaffner A. Induction of the CD163dependent haemoglobin uptake by macrophages as a novel antiinflammatory action of glucocorticoids. Br J Haematol 2002;1 19:239-43.

152 Kristiansen M, Graversen JH, Jacobsen C, Sonne O, Hoffman HJ, Law SK, Moestrup SK. Identification of the haemoglobin scavenger receptor. Nature 2001;409:198-201.

153 Schaer DJ. The macrophage hemoglobin scavenger receptor (CD163) as a genetically determined disease modifying pathway in atherosclerosis. Atherosclerosis 2002;163(1):199-201.

154 Yang F, Liu XB, Quinones M, Melby PC, Ghio A, Haile DJ. Regulation of reticuloendothelial iron transporter MTP1 (Slc1 la3) by inflammation. J Biol Chem 2002;277:39786-91.

155 Yeh KY, Yeh M, Glass J. Hepcidin regulation of ferroportin 1 expression in the liver and intestine of the rat. Am J Physiol Gastrointest Liver Physiol 2004;2:G385-94.

156 Henz S, Reichen J, Liechti-Gallati S. HLA-H gene mutations and haemochromatosis: the likely association of H63D with mild phenotype and the detection of S65C, a novel variant in exon 2. J Hepatol 1997;26(suppl 1):57.

157 Beutler E, Griffin MJ, Gelbart T, West C. A previously undescribed nonsense mutation of the HFE gene. Clin Genet 2002;61:40-2.

158 de Villiers JNP, Hillermann R, Loubser L, Kotze MJ. Spectrum of mutations in the HFE gene implicated in haemochromatosis and porphyria. Hum Mol Genet 1999;8:1517-22.

159 Worwood M, Jackson HA, Feeney GP, Edwards C, Bowen DJ. A single tube heteroduplex PCR for the common HFE genotypes. Blood 1999:94:405a.

160 Liechti-Gallati S, Schneider V, Neeser D, Kraemer R. Two buffer PAGE system-based SSCP/HD analysis: a general protocol for rapid and sensitive mutation screening in cystic fibrosis and any other human genetic disease. Eur J Hum Genet 1999;7:590-8.

161 Barton JC, Sawada-hirai R, Rothenberg BE, Acton RT. Two novel missense mutations in the HFE gene (I105T and G93R) and identification of the S65C mutation in Alabama hemochromatosis probands. Blood Cell Mol Dis 1999;25: 146-54.

162 Oberkanins C, Moritz A, de Villiers JN, Kotze MJ, Kury F. A reversehybridization assay for the rapid and simultaneous detection of nine HFE gene mutations. Genet Test 2000;4:121-4.

163 Piperno A, Arosio C, Fossati L, Vigano M, Trombini P, Vergani A, Mancia G Two novel nonsense mutations of HFE gene in five unrelated Italian patients with hemochromatosis. Gastroenterology 2000;1 19:441-5.
164 Bradbury R, Fagan E, Payne SJ. Two novel polymorphisms (E277K and V212V) in the haemochromatosis gene HFE. Hum Mutat 2000;15:120.

165 Rosmorduc O, Poupon O, Nion I, Wendum D, Feder J, Béréziat G, Hermelin B. Differential HFE allele expression in hemochromatosis heterozygotes. Gastroenterology 2000;119:1075-86.

166 Imanishi H, Liu W, Cheng J, Ikeda N, Amuro Y, Hada T. Idiopathic hemochromatosis with the mutation of Ala176Val heterozygous for HFE gene. Intern Med 2001;40:479-83.

167 Jones DC, Young NT, Pigott C, Fuggle SV, Barnardo MC, Marshall SE, Bunce M. Comprehensive hereditary hemochromatosis genotyping. Tissue Antigens 2002;60:481-8.

168 Le Gac GG, Dupradeau FY, Mura C, Jacalot S, Scotet V, Esnault G, Mercier AY, Rochette J, Ferec C. Phenotypic expression of the C282Y/ Q283P compound heterozygosity in HFE and molecular modeling of the Q283P mutation effect. Blood Cell Mol Dis 2003;30:231-7.

169 Kinkely SM, Brown BD, Lyng AT, Harrison WK, Schep GN, GoddardHill AC, Aubrey ME, Lillicrap D, Taylor SA. Absence of overt iron overload in two individuals compound heterozygotes for a 22 base pair deletion of exon 2 and the C282Y missense mutation of the HFE gene. Clin Genet 2003:63:163-5.

170 De Gobbi M, Daraio F, Oberkanins C, Moritz A, Kury F, Fiorelli G, Camaschella C. Analysis of HFE and TFR2 mutations in selected blood donors with biochemical parameters of iron overload. Haematologica 2003;88:396-401

171 Wallace DF, Dooley JS, Walker AP. A novel mutation of HFE explains the classical phenotype of genetic haemochromatosis in a C282Y heterozygote. Gastroenterology 1999;116:1409-12.

172 Wigg AJ, Harley H, Casey G. Heterozygous recipient and donor HFE mutations associated with a hereditary haemochromatosis phenotype after liver transplantation. Gut 2003;52:433-5.

173 Waheed A, Parkkila S, Zhou XY, Tomatsu S, Tsuchihashi Z, Feder JN, Schatzman RC, Britton RS, Bacon BR, Sly WS. Hereditary hemochromatosis: effects of $\mathrm{C} 282 \mathrm{Y}$ and $\mathrm{H} 63 \mathrm{D}$ mutations on association with $\mathrm{b}_{2}$-microglobulin, intracellular processing, and cell surface expression of the HFE protein in COS-7 cells. Proc Natl Acad Sci U S A 1997;94:12384-9.

174 Ramalingam TS, West Jr AP, Lebrón JA, Nangiana JS, Hogan TH, Enns CA, Biorkman PJ. Binding of the transferrin receptor is required for endocytosis of HFE and regulation of iron homeostasis. Nat Cell Biol 2000;2:953-7.

175 Wallace DF, Clark RM, Harley HA, Subramaniam VN. Autosomal dominant iron overload due to a novel mutation of ferroportin 1 associated with parenchymal iron loading and cirrhosis. J Hepatol 2004;40:710-3. 


\section{PostScript}

LETTERS

Correction: no evidence of an association between the T16189C mtDNA variant and late onset dementia (Gibson et al)

We believe that the title of Chinnery et al's paper should be corrected because the data the authors present do not include an analysis of the 16189 variant of mtDNA (Table 1).

We defined the 16189 variant as the DNA sequence associated with a polydC tract, resulting from a $\mathrm{T} 16189 \mathrm{C}$ transition that may generate heteroplasmic length variation, table 1. Heteroplasmic length variation does not occur when the polymeric tract is interrupted by a $\mathrm{c} \rightarrow \mathrm{t}$ transition, which occurs at several different sites but commonly at nucleotice 16186 or 16192 . Individuals with these additional polymorphisms are excluded from our definition of the 16189 variant because they no longer have a long homopolymeric c tract. The variant does not alter any coding sequences yet lies near to mtDNA control sequences, which can explain its effects on mitochondrial function. In studies of disease associations with variants in this region we chose to investigate the 16189 variant rather than any other sequence change, because of the likely functional effects of the homopolymeric $\mathrm{C}$ tract and heteroplasmic length variation.

Gibson et al ${ }^{1}$ have shown that the overall prevalence of the T16189C allele in their population is $12.6 \%$, which is substantially higher than the $6.4-8.8 \%$ prevalence of the 16189 variant reported in other studies. ${ }^{23}$ This is because they have quantfied the prevalence of the T16189C transition per se rather than the variant. Including these additional polymorphisms may dilute out a real association with the 16189 variant. The authors have shown that the $\mathrm{T} 16189 \mathrm{C}$ transition per se is not a risk factor for late onset dementia, ${ }^{1}$ but to our knowledge this has not, in any case, been implicated with any disease phenotypes. However, they found that the heteroplasmic length variation, which implies the presence of the 16189 variant, was associated with a 2.2 fold increased risk. They did not, however, quantify the relative risk for the 16189 variant per se, which could well be significant, in direct contradiction of their title. From their data, it is possible that the variant might in fact predispose to late onset dementia.

The 16189 variant is a risk factor for type 2 diabetes, ${ }^{4}$ thinness at birth, ${ }^{5}$ and aged 20 years $^{6}$ iron loading in haemochromato-

Table 1 Sequences of identified variants

\begin{tabular}{ll}
\hline Variant & Nucleotides \\
\hline Wild type sequence & ccccctcccc \\
$\begin{array}{l}\text { Sequences included in } \\
\text { Chinnery's analysis }\end{array}$ & $\begin{array}{l}\text { ccccccctcc } \\
\text { cctccccccc } \\
\text { ccccccccc etc } \\
\text { cccccccccc }\end{array}$ \\
$\begin{array}{l}\text { 16189 variant } \\
\text { Heteroplasmic length } \\
\text { variants included } \\
\text { within 16189 variant }\end{array}$ & $\begin{array}{l}c c c c c c c c c \\
\text { cccccccccc etc }\end{array}$ \\
\hline
\end{tabular}

sis, ${ }^{7}$ dilated cardiomyopathy, ${ }^{8}$ endometrial cancer, ${ }^{9}$ and other multifactorial disorders. ${ }^{10}$ This variant may be mildly detrimental. ${ }^{11}$ Unlike many other mtDNA polymorphisms implicated in type 2 diabetes, this variant probably has bona fide functional consequences because it has arisen many times independently in the various populations studied, ${ }^{2412}$ excluding a founder effect. Because the authors did not perform mitochondrial haplotyping ${ }^{1}$ to exclude a founder effect, their results may reflect the consequences of other co-segregating genes.

J Poulton, S Das

Nuffield Department of Obstetrics and Gynaecology, University of Oxford, Women's Centre, John Raddliffe Hospital, Oxford, UK

Correspondence to: Professor J Poulton, Nuffield Department of Obstetrics and Gynaecology, University of Oxford, Women's Centre, John Raddliffe Hospital, Oxford, OX3 9DU, UK; joanna.poulton@ obs-gyn.ox.ac.uk

doi: 10.1136/jmg.2004.019208

Received 13 February 2004

Accepted for publication 29 May 2004

Conflict of interest: none declared

\section{References}

1 Gibson AM, Edwardson JA, Turnbull DM, McKeith IG, Morris CM, Chinnery PF. No evidence of an association between the T16189C m+DNA variant and late onset dementia. J Med Genet 2004:41:e7.

2 Poulton J, Marchington D, Brown MS, Phillips D, Hagelberg E. Does a common mitochondrial DNA polymorphism underlie susceptibility to diabetes and the thrifty genotype? Trends Genet 1998; 14:385-7.

3 Miller K, Dawson J, Hagelberg E. A concordance of nucleotide substitutions in the first and second hypervariable segments of the human m+DNA control region. Int J Legal Med 1996;109:107-13.

4 Poulton J, Luan J, Macaulay V, Hennings S, Mitchell J, Wareham NJ. Type 2 diabetes is associated with a common mitochondrial variant: evidence from a population-based case-control study. Hum Mol Genet 2002;11:1581-3.

5 Casteels K, Ong K, Phillips D, Bendall H, Pembrey M. Mitochondrial 16189 variant, thinness at birth, and type-2 diabetes. ALSPAC study team. Avon Longitudinal Study of Pregnancy and Childhood Lancet 1999:353:1499-500.

6 Poulton J, Macaulay V, Livesey K, Wareham N, Parker E, Phillips D, Simmons D, Mayosi B, Knogali S, Robson KA. A common mtDNA variant may be a susceptibility factor in 4 important multifactorial conditions. Am J Hum Genet 2001;69(Suppl):579.

7 Livesey KJ, Wimhurst VL, Carter K, Worwood M, Cadet E, Rochette J, Roberts AG, Pointon JJ, Merryweather-Clarke AT, BassettML, Jovanolle AM, Mosser A, David V, Poulton J, Robson KJ. The 16189 variant of mitochondrial DNA occurs more frequently in C282Y homozygotes with haemochromatosis than those without iron loading. J Med Genet 2004:41:6-10.

8 Khogali S, Mayosi B, Beattie J, McKenna W Watkins $\mathrm{H}$, Poulton J. A common mitochondrial DNA D-loop variant is associated with idiopathic dilated cardiomyopathy in two different populations. Lancet 2001;357:1265-7.

9 Liu VW, Wang Y, Yang HJ, Tsang PC, Ng TY, Wong LC, Nagley P, Ngan HY. Mitochondrial DNA variant $16189 T \rightarrow C$ is associated with susceptibility to endometrial cancer. Hum Mutat 2003:22:173-4.

10 Momiyama Y, Furutani M, Suzuki Y, Ohmori R, Imamura S, Mokubo A, Asahina T, Murata C, Kato K, Anazawa S, Hosokawa K, Atsumi Y,
Matsuoka K, Kimura M, Kasanuki H, Ohsuzu F, Matsuoka R. A mitochondrial DNA variant associated with left ventricular hypertrophy in diabetes. Biochem Biophys Res Commun 2003;312:858-64.

11 Morten K, Jen C, Poulton J. The 16189 variant of mtDNA in type 2 diabetes: towards a molecular mechanism. Diabet Med 2003;20(Suppl 2):13.

12 Poulton J, Bednarz AL, Scott-Brown M, Thompson C, Macaulay VA, Simmons D. The presence of a common mitochondrial DNA variant is associated with fasting insulin levels in Europeans in Auckland. Diabet Med 2002:19:969-71.

\section{No evidence of an association between the mtDNA 16184-93 polyC tract and late onset dementia}

We are grateful to Professor Poulton and Dr Das for clarifying their definition of the 16189 variant. In our study we determined the allele status at position 16189 of mitochondrial DNA (mtDNA), and found no evidence of an association between the 16189C polymorphic sequence variant and late onset dementia. The title of our manuscript therefore reflects our observations and does not need to be corrected. Part of the confusion seems to have arisen because of different definitions of the "16189 variant" in the literature.

The standard "Cambridge" reference mtDNA sequence ${ }^{23}$ has a run of cytosine residues from nucleotide position (np) 16184 to 16193 interrupted by a thymidine residue at nucleotide position 16189. In approximately $12 \%$ of the UK population, there is a $\mathrm{T} \rightarrow \mathrm{C}$ substitution at $\mathrm{np}$ 16189. ${ }^{1}$ In most individuals this results a tract of $10 \mathrm{C}$ residues (polyC tract). This sequence is unstable and is associated with length variation of the polyC tract, probably because of slippage during genome replication, ${ }^{4}$ generating larger and smaller polyC tracts within the same individual during life (heteroplasmy). ${ }^{4}$ However, occasional individuals have other polymorphisms between np 16184 and 16193, which appear to stabilise the tract and do not lead to the generation of length variants. ${ }^{4}$ We suggest a more accurate definition should be used when referring to the homopolymeric $\mathrm{C}$ tract that is present in the majority of individuals with the T16189C substitution. The term "mtDNA 16184-93 polyC tract" will hopefully prevent confusion in the future.

Poulton and Das comment on the results of our logistic regression analysis (table 1 in our paper $\left.^{1}\right)$, and suggest that individuals with homopolymeric tract length heteroplasmy have a 2.2 fold increased risk of developing Alzheimer's disease (AD) compared with controls. This would imply an association between their definition of the 16189 variant and late onset dementia. However, the confidence intervals for the relative risk of 2.2 are 0.85 to 5.81 , comfortably including 1 . The relative risk is therefore not statistically significant and does not support a link between AD and homopolymeric length tract heteroplasmy.

In our original study, ${ }^{1}$ we measured homopolymeric tract length heteroplasmy using a trimmed PCR approach with a fluorescent forward primer. However, not all individuals with a 16184-93 polyC tract also have length heteroplasmy. Therefore, to address the concerns of Poulton and Das experimentally, we directly sequenced the relevant region of 
Table 1 Frequency of the mtDNA $16184-93$ polyC tract in control individuals, patients with dementia with Lewy bodies (DLB) and Alzheimer's disease (AD)

\begin{tabular}{|c|c|c|c|c|}
\hline \multirow[b]{2}{*}{ Group } & \multicolumn{2}{|c|}{$\begin{array}{l}\text { Frequency of the mtDNA } \\
16184-93 \text { polydC tract }\end{array}$} & \multicolumn{2}{|c|}{ Comparison with controls } \\
\hline & $\mathrm{n}$ & $\%\left(95 \% \mathrm{Cl}^{*}\right)$ & Odds ratio $(95 \% \mathrm{Cl})$ & pt \\
\hline Controls $(n=129)$ & 9 & 6.98 (3.24 to 12.83 ) & - & - \\
\hline $\operatorname{DLB}(n=97)$ & 10 & 10.31 (5.06 to 18.14 ) & $1.53(0.60$ to 3.93$)$ & 0.46 \\
\hline$A D(n=182)$ & 11 & 6.04 (3.06 to 10.56 ) & 0.85 (0.34 to 2.13 ) & 0.81 \\
\hline
\end{tabular}

*Exact 95\% confidence intervals for the percentage were calculated using the method of Clopper and Pearson. †Fisher's two tailed exact test. Cl, confidence interval. Each group corresponds to the cohort of neuropathologically confirmed cases and controls reported in our paper.[1] Note that table 2 of our original report[1] only includes subjects where the complete APOE genotype was also known. This data was not available for two controls, one DLB case, and eight $A D$ cases. The data from these cases are included in this table.

mtDNA in all of the cases and controls that harboured the $16189 \mathrm{C}$ variant in our original study, ${ }^{1}$ using an established protocol. ${ }^{5}$ The frequency of the mtDNA 16184-93 polyC tract in our original control population corresponded to values reported in other studies ${ }^{6}$ (table 1); $59 \%$ of control individuals with the T16189C polymorphic variant had a 16184-93 polyC tract, corresponding to publicly available control sequence data (http://www.genpat.uu.se/mtDB/). We found no evidence of an association between $\mathrm{AD}$ or dementia with Lewy bodies and 16184-93 polydC tract in a cohort or neuropathologically defined cases and controls, either by logistic regression analysis, or by directly comparing cases and controls with Fisher's exact test (table 1).

\section{Acknowledgements}

D M Turnbull and P F Chinnery receive support from the Wellcome Trust and the Alzheimer's Research Trust.

\section{S M Keers, A M Gibson, D M Turnbull,} P F Chinnery

Correspondence to: Dr P F Chinnery, Department of Neurology, The Medical School, Framlington Place, Newcastle Upon Tyne, NE2 4HH, UK; p.f.chinnery@

ncl.ac.uk

doi: 10.1136/jmg.2004.022467

Received 5 May 2004

Accepted for publication 9 May 2004

Conflict of interest: none declared

\section{References}

1 Gibson AM, Edwardson JA, Turnbull DM, McKeith IG, Morris CM, Chinnery PF. No evidence of an association between the T16189C mtDNA variant and late onset dementia. J Med Genet 2004;41:e7.

2 Anderson S, Bankier AT, Barrell BG, de Bruijn MH, Coulson AR, Drouin J, Eperon IC Nierlich DP, Roe BA, Sanger F, Schreier PH, Smith AJ, Staden R, Young IG. Sequence and organization of the human mitochondrial genome. Nature 1981;290:457-65.

3 Andrews RM, Kubacka I, Chinnery PF, Lightowlers RN, Turnbull DM, Howell N. Reanalysis and revision of the Cambridge reference sequence for human mitochondrial DNA. Nat Genet 1999;23:147.

4 Howell N, Smejkal CB. Persistent heteroplasmy of a mutation in the human mtDNA control region: hypermutation as an apparent consequence of simple-repeat expansion/contraction. Am J Hum Genet 2000;66:1589-98.

5 Taylor RW, Taylor GA, Durham SE, Turnbull DM. The determination of complete human mitochondrial DNA sequences in single cells: implications for the study of somatic mitochondrial DNA point mutations. Nucleic Acids Res 2001 ;29:E74-4.
6 Khogali SS, Mayosi BM, Beattie JM, McKenna WJ, Watkins H, Poulton J. A common mitochondrial DNA variant associated with susceptibility to dilated cardiomyopathy in two different populations. Lancet 2001;357:1265-7.

7 Livesey KJ, Wimhurst VL, Carter K, Worwood M, Cadet E, Rochette J, Roberts AG, Pointon JJ, Merryweather-Clarke AT, Bassett ML, Jouanolle AM, Mosser A, David V, Poulton J, Robson KJ. The 16189 variant of mitochondrial DNA occurs more frequently in C282Y homozygotes with haemochromatosis than those without iron loading. J Med Genet 2004;41:6-10.

\section{BOOK REVIEWS}

\section{Statistical Methods in Genetic Epidemiology}

By D C Thomas. Oxford University Press, 2004 $\$ 42.50$, pp 435. ISBN 0-19-515939-X

The contemporary research principles of genetic epidemiology are outlined in this book. The author clearly explains the research methodology and statistical analyses required to investigate important genetic epidemiological research questions. These include the following questions: Does a disease cluster in families? (familial aggregation); How does a disease cluster in families? (segregation analysis); Can familial aggregation be explained by genetic or environmental factors? (gene-environment interaction); Can we localise the genetic defect? (linkage and association studies). The theory is mainly illustrated with examples on the genetic epidemiology of cancer. As genetic epidemiology is a hybrid discipline, basic chapters on molecular genetics, epidemiology, statistics, and population genetics are included for those readers who need an introduction to any of these topics.

This book fascinates me because of its high didactic quality. The text is well organised and is easy to read. The content is interesting both to novices and to more advanced readers. The strength of the book is that it gives a complete overview of the different methods used in genetic epidemiology. Owing to its completeness, I would not be surprised if it were used in many semesters or courses on genetic epidemiology around the world. I would expect it also be very useful for the more advanced genetic epidemiologist as an up to date reference text. Readers interested in closely related disciplines such as population genetics, molecular genetics, behaviour genetics, statistical genetics, genomics, and bioinformatics will not find enough detail here and should look elsewhere.
I consider this text to be a standard work in genetic epidemiology and would advise both teachers and researchers in the field to read and use it.

M P Zeegers

\section{Human Evolutionary Genetics: Origins, Peoples \& Disease}

Edited by M A Jobling, M E Hurles, C TylerSmith. Garland Science, 2003, £35.00 pp 458. ISBN 9-780815-341857

With the near completion of the human genome sequence, and the exponential increase in associated information on inter-individual variability, there are enormous opportunities for using these data. Evolutionary geneticists are attempting to understand our origins and revisit the questions of the relative role of selection and drift. For medical geneticists, the search is now on for the genetic causes of complex disease, while forensic science is increasingly exploiting our interindividual differences to solve crimes. All these topics are inextricably linked. This super textbook covers almost everything an undergraduate student in human genetics would need as a basis for any of these areas, but will in fact have a much wider readership. It starts as far back as the structure of DNA, chromosome structure, meiosis, mitosis, and so on, while covering in some depth anthropological and archaeological evidence for the origins of modern humans, the extent and nature of genomic variation, and the principles of human population genetics. It explains clearly how the genome can be considered in blocks, owing to the pattern of historic and prehistoric recombinations and that these pieces of DNA, as well as the Y chromosome and mitochondrial DNA, track back to many ancestors who may have lived in different parts of the world.

This publication is timely, up to date, and has enormous and comprehensive coverage, without being too heavy to carry or costing too much. It is more than just a textbook, because, by using opinion boxes, it discusses contentious and problem issues. Thus as well as providing factual information, the book will stimulate the undergraduate to appraise observations and their interpretation critically. An important example is the discussion of error rates, and the potential impact of errors on interpretation of data. It answers questions that many of us get asked by our non-genetics friends, such as what exactly do we mean when we say that there is $1-2 \%$ sequence difference between humans and chimpanzees? How much do the different population groups of the world differ and is the term race meaningful? Clearly, as far as humans are concerned, it is not.

The book will also serve as a very useful introduction to molecular and population genetics for epidemiologists, anthropologists, and others who are new (or indeed not so new) to the field. It contains a wealth of information relevant for medical geneticists who are embarking on association studies. This, for example, includes the effects of selection and the effects of population admixture.

The book is very well laid out, with chapters grouped in six main sections, each of which aims to answer a question (Why study evolutionary genetics? How do we study genome diversity? How do we interpret genetic variation? Where and when did humans originate? How did humans colonise the world? How is an evolutionary perspective helpful?) There is a 
good index and glossary, so that it is easy to look things up, and there are extensive references at the end of each chapter and recommendations for further reading. Indeed there are but few short-comings. The figures and tables, which are on the one hand very useful and informative, do also have some weaknesses. Whether it is my failing eyesight or heterozygous manifestation of a colour vision anomaly, I often found the blue grey and black shadings and characters extremely difficult to distinguish. The figure legends could also sometimes have been more informative. However Mark Jobling and colleagues are to be congratulated-this book is a good buy, an excellent read, and is to be strongly recommended.

\section{M Swallow}

\section{CORRECTIONS}

doi: 10.1136/jmg.2004.020644corr l

In the paper Recent advances in understanding haemochromatosis: a transition state (JMG 2004;41:72l-30) figures 1 and 2 were incorrect. Below are the corrected figures.

$\mathrm{Al76CV}$ has been changed to Al76V and R224G has been changed to R224Q in figure 1 .

N114D has been changed to N144D in figure 2. The journal apologises for these errors.

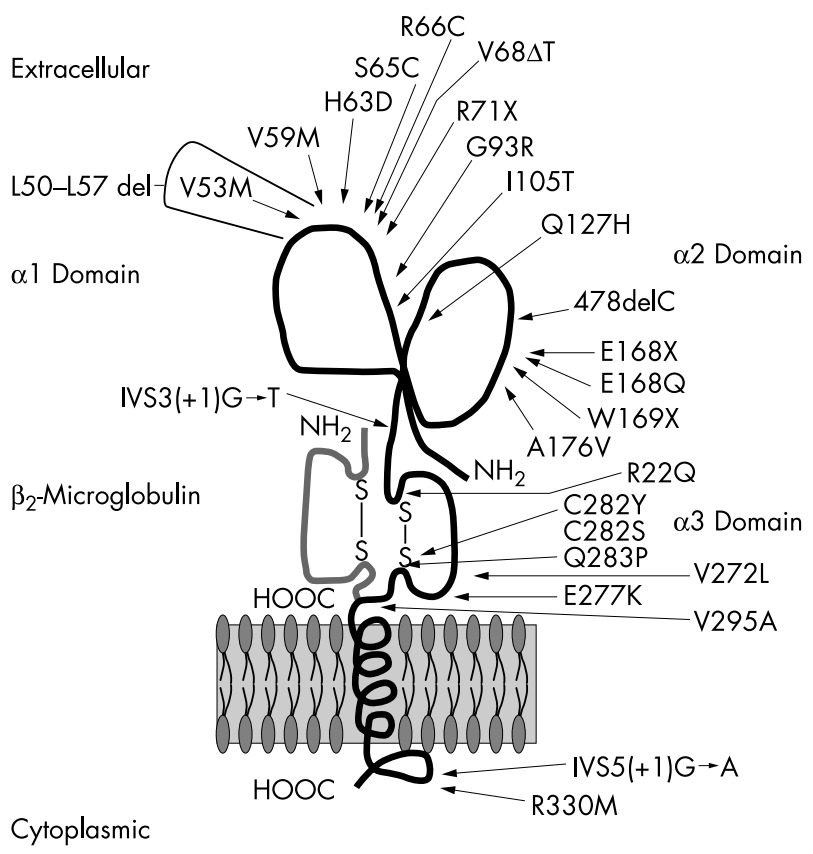

Figure 1

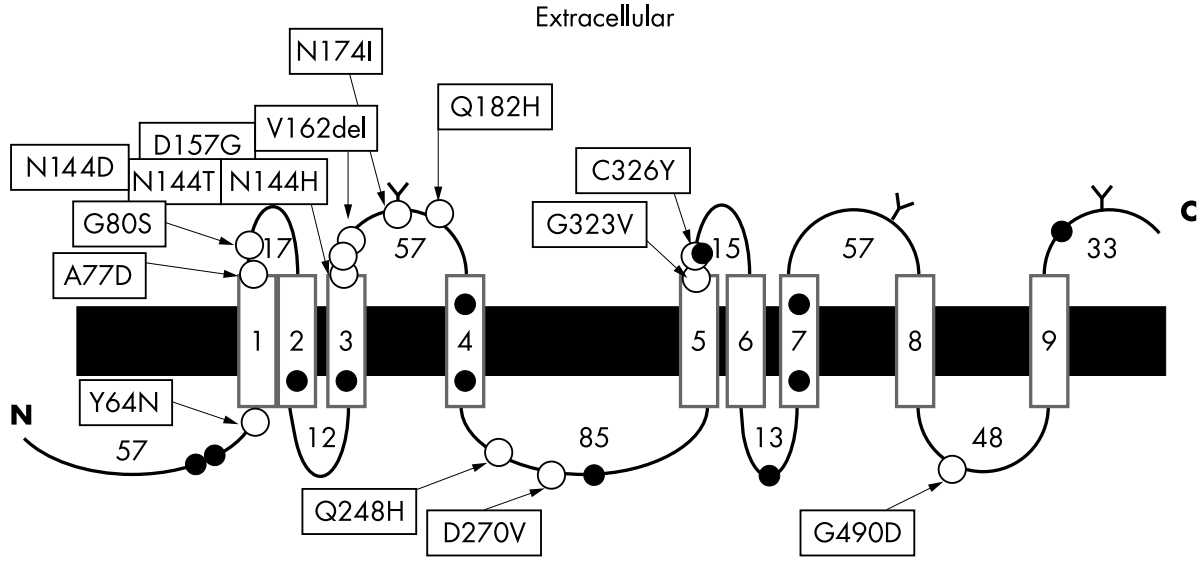

Cytoplasmic

Figure 2 
doi: 10.1136/jmg.2004.022111 corr l

In the paper Recent advances (JMG 2004; 41:814-25) figure 2 was incorrect. Below is the corrected figures.

A small black bar has been inserted on the line representing the deletion present in the patient number 3273 . The author apologies for this error.

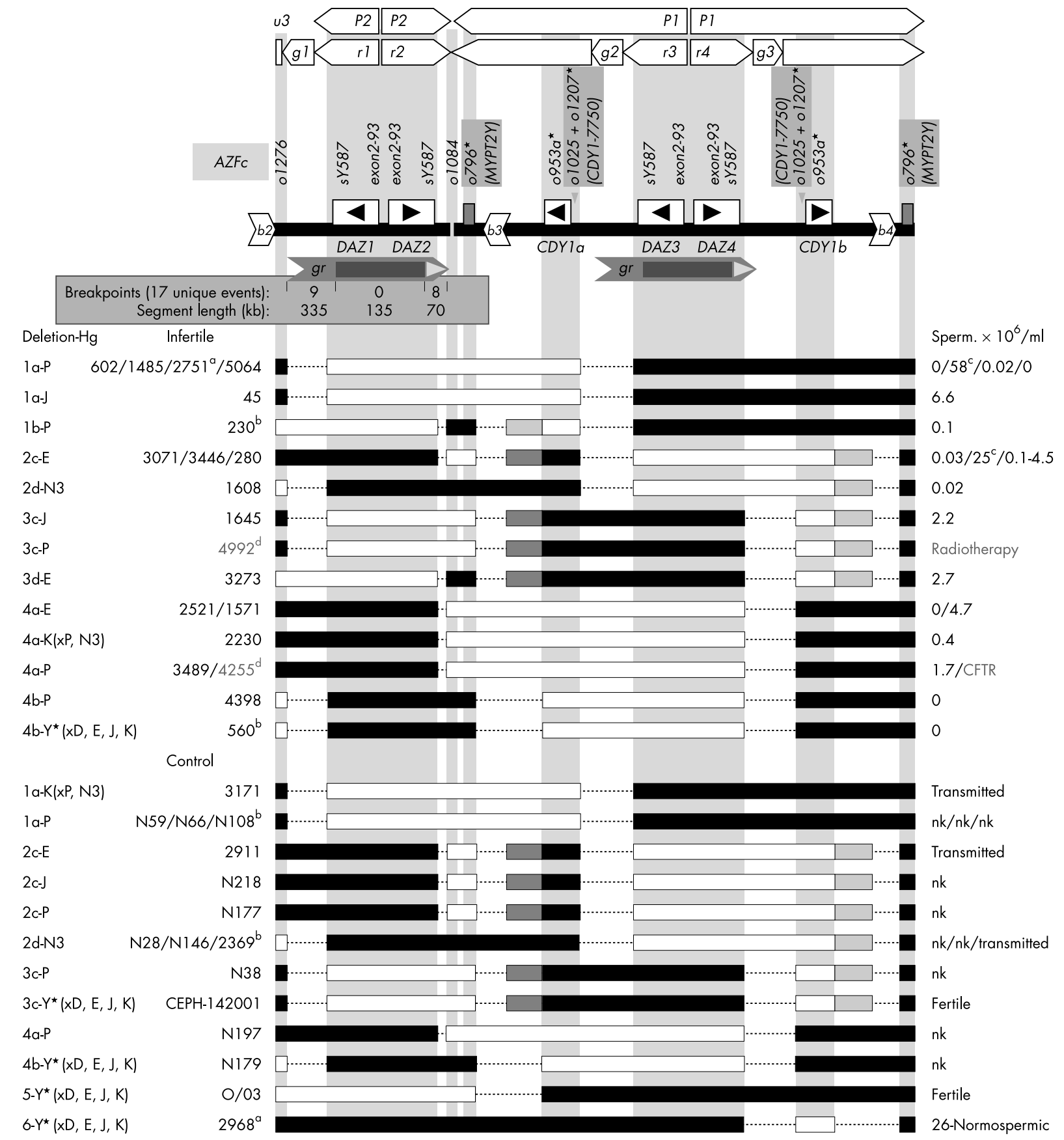

Figure 2 